\title{
Sustainable Land Tenure and Land Registration in Developing Countries, Including a Historical Comparison with an Industrialised Country
}

Final Version 15 January 2003

\section{Approved for Publication in the Computers, Environment and Urban Systems 2003; \\ Third Special Edition 'Cadastral Systems'. Elsevier Science Ltd.}

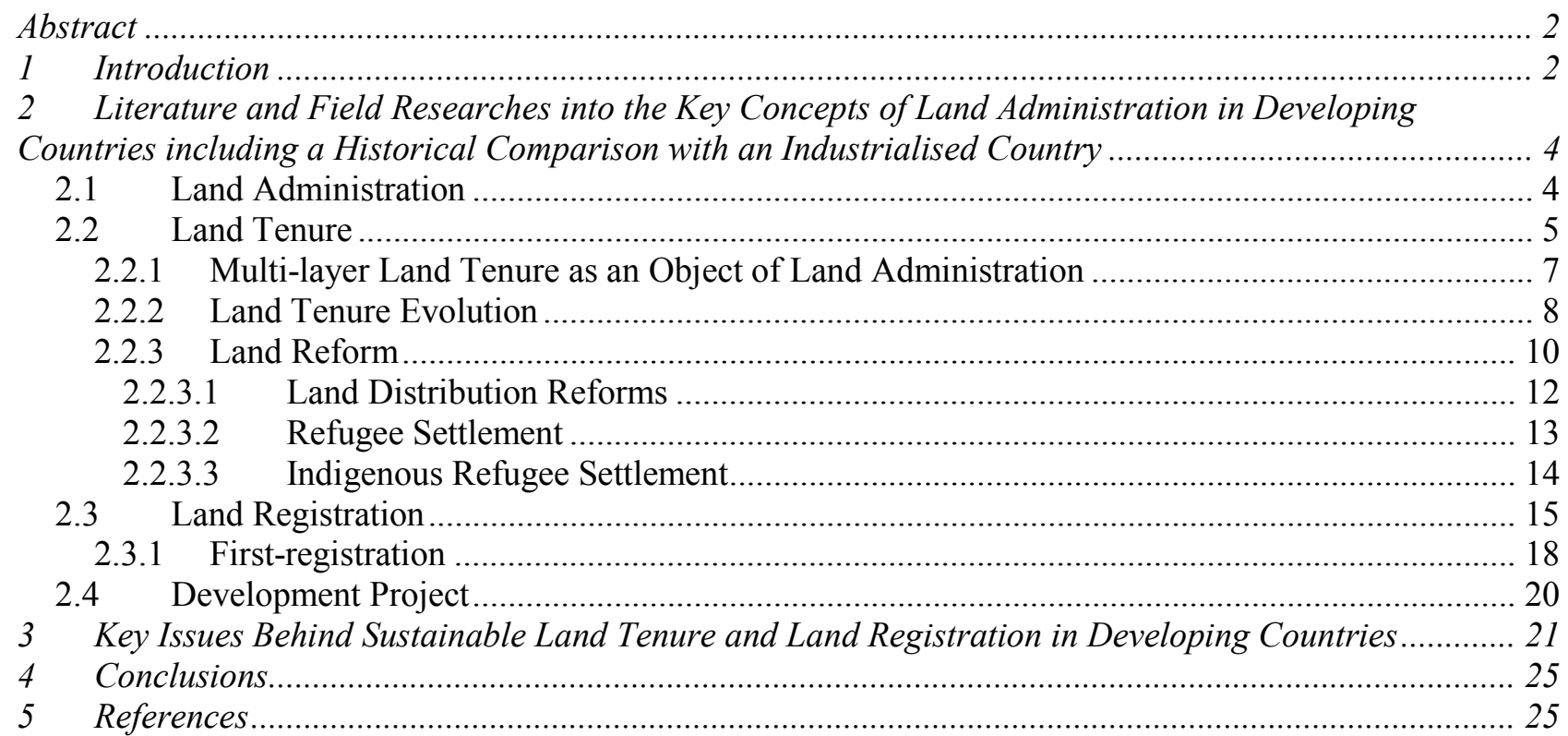

\footnotetext{
AUTHOR

Mika-Petteri Törhönen

FM-International Oy FINNMAP

P.O. Box 14

FIN-00511 Helsinki

FINLAND

Tel. +35897744260

Fax. +358977442650

Mob. +358405621062

E-mail: mika.torhonen@finnmap.com

Web site: http://www.finnmap.com/
} 


\title{
Sustainable Land Tenure and Land Registration in Developing Countries, Including a Historical Comparison with an Industrialised Country
}

\begin{abstract}
This article investigates sustainable land tenure and land registration in developing countries. The results of four case studies are integrated within a basic framework that was compiled from a literature study. The result is an interpretation of the framework of developing country land tenure and land registration with key issues and their relative impacts on a) the feasibility of land administration and b) sustainable development. This article shows the complexity and multi-dimensional nature of land administration, land tenure and land registration development in this context. The main conclusions are firstly that workable land administration is built upon good governance, appropriate resources, cultural sensitivity, equity, quality and commitment, and secondly that sustainable development is best promoted by secure, flexible, all-inclusive land tenure structures.
\end{abstract}

\section{Introduction}

Imagine a country where nobody can identify who owns what, addresses cannot be easily verified, people cannot be made to pay their debts, resources cannot conveniently be turned into money, ownership cannot be divided into shares, descriptions of assets are not standardised and cannot be easily compared, and the rules that govern property vary from neighbourhood to neighbourhood or even from street to street. This is how Hernando de Soto (2000, p. 12) brilliantly captured the developing country reality from the point of view of a property system, or rather the lack of it. This article constitutes my fourth ${ }^{1}$ and final publication in a research series on land tenure and land registration in conditions similar to those described above. In fact this chapter could well be introduced by the words: Imagine establishing a land registration system in a country where nobody can identify who owns what, addresses cannot be...

While de Soto summed up post-communist and developing countries as embodying an identical "deadcapital" phenomenon, I found developing countries to be difficult to define as a homogeneous group, at least in the context of land tenure. Consequently I targeted poor countries and also rich countries with a poor past, where land administration was facing severe challenges and where a land registration development project was either planned or being implemented. I aimed to define key issues behind sustainable land tenure (including land reforms) and land registration (stressing first-registration). In practical terms, I take a land tenure system or a land register to be sustainable if it manages to administer land effectively and to reflect the actual relationships between people and land. At the very least a land register should be updated to reflect inter-family alienations and land parcel mutations. However, in terms of sustainable development ${ }^{2}$ this is not enough. Land tenure and land registration have to promote development. Such a situation is assumed to be a rarity in developing countries, which leads to the research problem: What causes this? And to the research challenge: What are the key issues that could reverse such a situation? Consequently, I have focused on attempts at improvement, a relief considering the enormity of developing country problems. I concentrate primarily on rural matters, but not exclusively. I combine the basic framework of the research with articles from internationally published land administration research and statements. Research material is amazingly freely available, partly due to the improved global information links, and partly since land issues are so topical $^{3}$ worldwide, particularly for developing countries. My aim is to clarify international understanding on key issues in land tenure and registration. In an additional strand, I analyse the feasibility of land administration development projects, looking at aims, means and pre-conditions behind successes and failures.

\footnotetext{
${ }^{1}$ The other three are Törhönen 2001, Törhönen 1998a and Törhönen \& Goodwin 1998.

${ }^{2}$ See Chapter 2.4. for the origin and definition of the term sustainable development.

${ }^{3}$ See Chapter 2.4. about the global interest in land matters.
} 
This research includes four case studies involving field research in three developing countries ${ }^{4}$. In addition to the fieldwork, in order to understand the present through the past, extensive literature surveys were carried out. These case studies have been published (Törhönen 2001, Törhönen 1998a and Törhönen \& Goodwin 1998) and there is no need to repeat the details. Instead, I compare the findings with the combined framework of key issues and with the fourth case as presented below. The two African countries and the South East Asian cases differ markedly and cover a wide range of developing country land administration issues. All had as an objective a land registration programme intended to solve a number of micro-scale issues and which also had broad, macro-scale aims. Zanzibar was the target of the broadest case study of this research. There, the evolution of land tenure, land reforms and land policy development were all investigated. The connection between the history, culture and land tenure both in the past and present, the confusion that results from constant land tenure reforms, and the all-time-low security of tenure of secondary landholders with historical consequences, were the subject of important findings. A first-registration pilot and a new land tenure statute were analysed and a land registration development project was evaluated in internationally recognised frameworks (Törhönen 1998a, p. 76 - 86). The Zimbabwean case study was narrower in scope and targeted communal tenure under pressure. The current status of land tenure and administration, the planned direction for titling and technical means of first-registration were analysed and some new approaches tested. Gender and good governance issues were also singled out as being topical. Finally, the Cambodian case showed de Soto's reality in its purest form. The current status of the country and its land tenure and land administration, recovering as it is from years of turmoil, proved to be a shock. Research into land registration revealed a troubled system that provides little or no assistance to its intended beneficiaries. But Cambodia also showed the winds of hope more strongly than the other cases. The young national land registration programme is promising, and the fact that is was adopted at all. Its terms of reference, people-oriented approach, feasibility and technical and legal establishment show that change is possible.

Hernando de Soto explored reasons why developing countries have not developed to the same extent as Western countries. According to his article, the industrialised countries' past is the present for many developing countries (2000, p. 9), and de Soto urges us all to learn from the lessons of history. Acting on this logic, as my fourth case study I carried out a literature research on the evolution of land tenure and land administration in Finland. Finland has not long been a rich, industrialised, country. Until very recently it was largely, and until last century entirely an agricultural country, one of the poorest in Europe. Its past is thus comparable with the present of an agricultural developing country. The evolution of land tenure from a customary form through semi-communal village tenure to individual tenure is compared with similar developments in Zanzibar, as is the evolution of small peasants' rights from occupation-against-labourcontribution, through leasing up to private tenure. The several refugee resettlement dealings on the part of Finland provide very relevant points of view and also invite comparison with Zanzibar and Cambodia. The Skolt-Sami, for instance, provide a example of an indigenous group that had to relocate to inland Finland when their villages were lost in the Second World War. How their land tenure and resettlement was organised is relevant to topical concerns both in Cambodia and Zimbabwe. Western countries are eager to advise developing countries on the treatment of indigenous groups and their land tenure issues, but we need to ask how well those countries have managed to do the job themselves. Although no identical systematic land registration campaign exists in Finland, a series of land reforms provide reference points for all of the case study registration programmes. The technical achievements of Finnish land administration are no doubt significant, but less notice has been paid to them since they fall outside the scope of the research ${ }^{5}$. However, reference is made to technicalities where deemed relevant.

In the end, I have attempted to create a framework for sustainable land tenure and land registration in developing countries with key issues valued for their relative significance a) to the feasibility of land administration and b) to sustainable development. Finally, I highlight the main conclusions. The justification for my work stems from a wish to contribute to the design and implementation of land administration

\footnotetext{
${ }^{4} 1^{\text {st }}$ in Zanzibar several research studies between $1991-1995,2^{\text {nd }}$ in Zimbabwe 1996 and $3^{\text {rd }}$ in Cambodia 1999.

${ }^{5}$ It is noted that the importance of increasingly available and affordable information and communication technology for developing country land administration is not questioned; on the contrary, it is seen as a topic in its own right.
} 
development projects. There is a real struggle out there in de Soto's world, and there is no time and no resources to waste.

\section{Literature and Field Researches into the Key Concepts of Land Administration in Developing Countries including a Historical Comparison with an Industrialised Country}

Land administration colleagues from different countries frequently find themselves arguing about terminology. For example, what is "land management" to one person may be "land administration" to another, and what is "land registration" to one may be "cadastre" to another. Most importantly, what is done for security of ownership by one may be done for taxation purposes by another. It is difficult, if not impossible, to formulate a general, global concept of land administration, because different systems have evolved over hundreds of years and reflect the culture and the society they serve. Therefore, the following literature study findings on the key theories and concepts of land administration that constitute a basic framework of land tenure and land registration should not be taken to fit in anywhere in particular. Wherever a key concept is defined I have critically compared it to my case study findings.

\subsection{Land Administration}

First, I will try to place land administration in a broader context. The highest level in a land hierarchy is land policy, which falls under the national development plans of a country (Dale \& McLaughlin 1998, p. 160). In this context land policy is taken as a governmental instrument that states the strategy and objectives for the social, economic and environmental use of the land and natural resources of a country ${ }^{6}$. It is considered of the utmost importance that a country trying to organise its land matters starts with the development of a land policy that fits in with national objectives and leads to concrete actions ${ }^{7}$. This is by no means always the case. Land matters are often dealt with by numerous, scattered organisations without a common strategy, an aim or cooperation (Dale \& McLaughlin 1998, p. 61). Cambodia still had just such a situation in 1999 (Törhönen 2001, p. 410-415), but since then the process of preparing a comprehensive land policy has been started. Zanzibar had already prepared a modern land policy by the 1980's, which was advanced for the region at the time (Törhönen 1998a, p. 56-58). However, Zanzibar provides an example of a place where policy and legislation are way ahead of their implementation. In the Zimbabwean communal lands, the numerous land administration players definitely did not share the same goals (Törhönen and Goodwin 1998, p. 99). Apparently the government of Zimbabwe had noticed this, because a comprehensive rural land tenure policy forming initiative was in place by the time of my field research.

Land administration is one, if not the main land policy instrument ${ }^{8}$. As Germans (GTZ 1998, p. 163) put it, land administration includes the regulations and measures of the rights to land (land tenure), the use of land and the valuation of land. Dale and McLaughlin (1998, p. 1) add to this the alienation, development and transfer of land. Land administration enhances legality and provides information about land. Its components may differ, but a relative consensus prevails on its core function, namely that of land registration ${ }^{9}$ and of the basic unit of the cadastral parcel. The term Land management ${ }^{10}$ is often encountered. Henssen (1994, p. 3) interprets land management as being almost equivalent to land administration as defined by others, with only planning added ${ }^{11}$. The line between these terms is neither static nor significant. The relationship between the two is as follows, that land management implements land policy by means of land administration. Land management is a positive and creative activity that aims at sustainable land use, while land administration is

\footnotetext{
${ }^{6}$ See GTZ (1998, p. 140) for an attempt to establish the principle objectives of land policy.

${ }^{7}$ See Williamson and Ting (2001 p. 339-366), who pledge a "holistic" approach and have a vision of "a clear road map" to guide the country's land administration sub-projects towards contributing to the common goals.

${ }^{8}$ See GTZ 1998 p. $147-148$ for an attempt to list the land policy instruments.

${ }^{9}$ Other components are land markets, land banking, land valuation and property taxation (GTZ 1998, p. 163-178)

${ }^{10}$ Management of land use and development, and policy preparation (Dale and McLaughlin 1998 p. 163, FIG 1995)

${ }^{11}$ Common terms such as (Cadastre-Based) Land Information Systems (Barnes 1990) and Spatial Data Infrastructure (Williamson and Ting 2001) were ignored, as the primary idea was not to analyse nor to create definitions.
} 
an implementer that follows the law and enhances it. The point is that land management without proper land administration operates without any connection to reality. This is often the case in developing countries. The foundation is weak, thus making land management a kind of abstract art. I witnessed in Cambodia how urban parcelling was done on paper without reference to the situation on the ground, resulting in new rights to land being issued overlapping with existing ones and nature reserves being established without knowing their location (Törhönen 2001, p. 412-413). In the communal lands of Zimbabwe (Törhönen and Goodwin 1998, p. 99) an administrative boundary dispute was solved completely irrationally since base data and the responsibilities of different authorities were neither clear nor followed. As in Cambodia, Zimbabwean farmers saw their holdings as being threatened when, for example, a new game reserve was planned in their area. In both cases, a rule that vested lands in the government, no matter how nominal that rule was intended to be, made occupants vulnerable to any authoritative decision. In Zanzibar, the government-granted useright parcels ${ }^{12}$, which according to the law were meant to be three acres, varied from between two and fourteen acres (Törhönen 1998a, p. 39). Such a thing was only possible owing to the absence of detailed surveys or recorded data on the allocated parcels. In conclusion, developing countries still have to concentrate on the basics. This is why I investigated the basics of land administration, namely land registration. However, this research without land tenure would be unfruitful, since land tenure provides the real challenge for land registration in developing countries.

\subsection{Land Tenure}

Land tenure is an interdisciplinary term ${ }^{13}$ with multiple meanings. The difficulty with definition starts from the object referred to. Land tenure rights exist to land, to immovable property, to real estate, to real property or to other forms of land holding unit. In the most extreme case are (post) socialist countries, for example Uzbekistan where property rights exist to attachments on land only and not to the land itself (Törhönen 2002). The same applies to Zanzibar, but there, use-rights establish de facto freehold tenure (Törhönen 1998a, p. 62), which is not the case in Uzbekistan. Since post-Soviet Union transitional tenure systems are not the primary focus of this research, I apply Dale \& McLaughlin's (1998, p. 16) definition according to which land covers a limited area and its permanent attachments, and property refers to the abstract nature of land, which includes rights, duties and customs that are related to that piece of land. The term real property is taken to cover both land and property. The abstract nature proves to be a very broad category, and this issue will be explored further.

Turning to land tenure itself, land registration professionals (Simpson 1976) used to consider land tenure from a rather narrow point of view as being the manner of holding (real) property. A more sociologically oriented school preferred to view land tenure as relationships between individuals and groups that define their relation to land (Birgegård 1993, p. 1). This has influenced current land professionals, who may define land tenure as the relationship (rights, restrictions) between people and land (GTZ 1998, FIG 1995). The term land tenure system is often used, which includes the mechanism for implementing land tenure (Dale \& McLaughlin 1998, GTZ 1998). Due to the elastic, indefinable nature of land tenure in developing countries I do not use the word system. That word implies an organisational framework, often alien to developing countries. I prefer to describe modes of relationship between people and land, referring to the existing land tenure practices rather than to a system.

Land tenure can be classified into main categories, most of which are marginal in the industrialised countries. In developing countries, on the other hand, both statutory ${ }^{14}$ and customary $^{15} /{ }^{16}$ tenures are strong. If a developing country land administration only recognised the codified, statutory tenure, then large parts of de Soto's reality would be ignored, which would boost the informal sector ${ }^{17}$ and ultimately lead to failed land administration. Regarding Zanzibar, I found how secondary, temporary, rights in land provided a crucial

\footnotetext{
${ }^{12}$ See more about these use right parcels in Chapter 2.2.3.1

${ }^{13}$ At least legal, social, economical and technical disciplines interlink with land tenure.

${ }^{14}$ Statutory tenure means written, codified, rules that define the relationship between land and people.

${ }^{15}$ Customary tenure rights and restrictions obeyed by a society are not written, but literally based on custom.

${ }^{16}$ More: Birgegård 1993, p. 8-11, Simpson 1976, p. 220-238, Dale \& McLaughlin 1998, Deininger \& Binswater 1998.

${ }^{17}$ More about formal and informal properties in de Soto (2000) and Dale and McLaughlin (1998, p. 26-27).
} 
source of food and social stability. However, the new land tenure act ignores those rights and consequently lessens the security of tenure i.e. weakens the source of living of many if not the majority (Törhönen, 1998a p. 63,91$)^{18}$. Often statutory tenure is secured by a stipulation that only registered interests in land qualify as proof of title, but this can be problematic. For example in Zanzibar (Törhönen 1998a, p. 62), only registered interests in land can be transferred. Since only a fraction of parcels are registered, most transactions are illegal (Törhönen 1998a, p. 92). In Cambodia, unregistered land ${ }^{19}$, whether occupied or not, was subject to local government's unlimited power (Törhönen 2001, p. 412). Why then would landholders not register their rights in the case of a transaction? One reason is that it may not be feasible due to an ineffective administration and informal payments, as in Cambodia (Törhönen 2001, p. 414). Another reason was seen in Zanzibar, where outdated transfer and inheritance restrictions forced secret transactions (Törhönen 1998a, p. 35-37). These cases prove how difficult it is to legislate sustainable statutory tenure in a developing country. Yet, customary tenure systems have managed for a long time. Characteristically in customary tenure systems land is not alienable and individual interests cannot be transferred, although individual farming units may be allowed. Grazing and cultivation are often based on nomadic and shifting practices. Customary tenure is seldom codified, but there are many countries, especially in Africa, where customary rules have been recognised as law. Recognised or not, the co-existence of two tenure groups potentially causes problems (Fourie \& Hillerman 1995) although it may provide relative harmony. But commonly in developing countries both statutory and customary tenure rules are followed half-heartedly, which leads on to perhaps the largest category of tenure, namely that of undefined, multidimensional, ambiguous and elastic; multilayer tenure. I differentiate its features from the characteristic flexibility or individualisation of customary tenure (Birgegård 1993, p. 10, Simpson 1976, p. 225-226). In Zimbabwe (Törhönen and Goodwin, 1998, p. 98), customary tenure struggled to attract the younger generation, who often wanted to break with the traditional way of life. This transition was exacerbated by accusations that customary rulers had abused their positions therefore losing respect. The current situation might be called transitional tenure, but this would be misleading because that term connotes a transition from collective to private ownership. Though both exist, the transition from customary to statutory tenure systems is more relevant to developing countries than the transition from a collective statutory to a private statutory form of land tenure.

The real issue at stake is security of tenure, which already Simpson (1976 p. 8-9) has linked to development. He pointed out that security of tenure is not equivalent to secure ownership, and that codified/recorded tenure is not a prerequisite for secure tenure. Customary tenure systems have provided an adequate basis both for development and for commercial applications. Lawrance (1972), favouring customary tenure, pointed out that the purpose of title registration is not to change tenure, only to secure $\mathrm{it}^{20}$. He even proposed that individual rights should be subject to transfer restrictions ${ }^{21}$ and that group-interests should be registered in a similar fashion to individual rights. But up to now cadastral reform has often gone hand-in-hand with land tenure reform by formalising or upgrading customary or spontaneous occupancy tenure systems (FIG 1995). According to Deininger and Binswanger (1998), the World Bank land reform policy in the seventies recommended that communal tenure systems, like most customary tenure, should be transformed to freehold. More recently cases are recognised where communal tenure is more secure, supports better transfer and is more cost-effective than freehold tenure ${ }^{22}$. Consequently, the World Bank advocates an approach that favours the gradual evolution of communal tenure rather than changing it altogether. It took some thirty years to understand what was known already. In Zanzibar there are customary tenure forms that have survived a series of radical reforms over centuries (Törhönen 1998a). The land reforms were in rapid succession but were never rigorously implemented. The result is a mess of customary and statutory, formal and informal land tenure practices where a general rule is difficult, if not impossible to determine. I have called it confused land tenure, a multi-layer tenure of the worst kind (Törhönen 1998b). It is fair to note that "transition" and "confusion" are not merely land tenure issues. As de Soto (2000) relates, developing countries and countries in transition frequently lack overall clarity in relation to all types of property. Having said all of the above, in the land administration context land tenure essentially defines quantitative interests

\footnotetext{
${ }^{18}$ See more about the complicated land and tree tenure and land borrowing in Zanzibar in Chapter 2.2.1.

${ }^{19}$ Unregistered holdings in the eyes of the law were squatting, or at least that conclusion could be drawn, if wished.

${ }^{20}$ Lawrance saw individualisation as lethal to social security causing enlarged holdings and landlessness. Customary land tenure systems promote a sense of communal responsibility and enable land to be preserved for future generations.

${ }^{21}$ For more about the functionality of land use and transfer restrictions see Chapter 2.2.3.1 and 2.2.3.3.

${ }^{22}$ The WB has even explored rental systems' potentially wider access to land than sale-based systems'.
} 
in land. The land administration and land registration challenge lies in the ability to quantify, recognise, record, regulate and manage land tenure, which consists of multiple layers that have volatile formal and informal significances.

\subsubsection{Multi-layer Land Tenure as an Object of Land Administration}

Zanzibar land tenure is an example of a difficult case of land administration where it is debatable which of the many layers prevails (Törhönen 1998a). The legal system may not be dominant, and land may not even be the object. For example, Zanzibari customary tenure structures share a common phenomenon that allows trees and land to be held by different owners. Double-cropping systems, one from trees and the other from soil, are common. Zanzibari trees have provided cash crops for two centuries while land is still largely under subsistence crops, making tree ownership more important than the land (soil). A recent Land Tenure Act establishes a secondary right to own trees on another person's land. In a test land registration, no cases of this sort of secondary right were met. The tree owner always, apart from communally held land, had the strongest, although not necessarily absolute, claim to land, i.e. a tree-owner was considered to be the landowner (Törhönen 1998a, p. 50-51). But a high incidence of land-borrowing was found, meaning cultivation other than landholder's seasonal crop taking place under the landholder's trees. This custom is based on mutual benefit and agreement between the soil and the land (tree) holders. It still enables significant subsistence cultivation to take place, which, combined with subsistence fishing, has formed the basis of the survival strategy for rural Zanzibaris. However, the rights of land borrowers are not recognised by the new Land Tenure Act (Törhönen 1998a, p. 63). In fact the soil users' security of tenure has always been weak, a fact that has been the driving force behind several historical events, in one case a revolution ${ }^{23}$. There have been eras of stability, but when social pressures have grown and required tenure changes, the soil holders have always suffered. Unfortunately, the new statutory tenure has not been influenced by the lessons of history and soil users are still ignored.

But would it be possible for the Zanzibari land administration to recognise all tenure layers? And the answer is not easily, because secondary rights are of necessity very flexible to enable soil users to react to changing conditions dynamically. A registration system could hardly react as quickly. Nor is it feasible to register land-borrowing rights, because it would require an exact clarification and limitation of rights, which runs counter to their nature. It would potentially lessen the tenure security of primary right holders in a manner that would endanger the trust needed for transactions and mortgaging, which are a prerequisite for desirable long-term investment. Borrowing the logic of Libecap $(1989$, p. 23), who sees the emergence of property rights as a political process, it is noted that informal rights to land might even be better off if no attempt is made to recognise them formally. This is due to the political implications that a skewed distribution of land may accelerate once exposed. Nevertheless, it is suggested that strengthening weak secondary rights should be the general rule, perhaps along the lines of the common right that exists in Finland ${ }^{24}$. The same principle in Zanzibar could create general access to idle cultivable soil provided that the primary landholder's interest was not harmed. The rule could embody a mechanism to compensate for inputs invested by the secondary right holder should the primary right holder interrupt a cultivation season. Africa needs to investigate flexible alternatives to existing statutory tenure systems; in particular, common-right models could be researched further in this context. A standard solution to multi-layer tenure regulation, namely the introduction of communal titles, was explored in the Zimbabwean case study (Törhönen and Goodwin 1998, p. 102-103, 108). It was an attempt to provide the security of tenure afforded by a title system while stopping short of introducing individualised tenure. Findings pointed out that it was unclear whether such a system would be capable of providing the benefits of a title system. Simpler solutions, like strengthened gender equality or micro-scale credit were seen as potentially more beneficial than communal forms of title. At least, we called for the possibility of upgrading tenure where suitable conditions obtained while permitting natural land tenure evolution elsewhere.

\footnotetext{
${ }^{23}$ See Chapter 2.2.2 on how the insecurity of secondary land rights affected the 1964 revolution.

${ }^{24}$ It provides public access to nature for passing through, temporary stays, mushroom and berry etc. picking, fishing and hunting (subject to fishing and hunting regulations) on private and public rural land and waters outside home yards.
} 


\subsubsection{Land Tenure Evolution}

Land tenure is subject to an evolution that reflects changes in a society. This was particularly evident in the Zanzibar case study (Törhönen 1998a, p. 15-54, 87-90). The history of two customary land tenure forms, namely Shirazi tenure ${ }^{25}$ and cash crop tree-plantation tenure ${ }^{26}$, were researched to assess their impact on current tenure. Libecap (1989, p. 116) showed how property right options should be seen within a framework that has evolved over history. Shirazi tenure (Törhönen 1998a, p. 16-20, 45-49), based on family-held home yards, tree ownership and communally held farmlands, has survived better than plantation-tenure. Relics of Shirazi communal tenure can still be traced back in coastal Zanzibar. However, lately the increasing population and commercialisation have impacted on life in the coastal (Shirazi) villages, which have always been more oriented towards the sea than the land. Cultivation areas have mainly been under subsistence farming with low economic returns. But recently, beautiful Zanzibari beaches have become tourist attractions, thereby weakening communal tenure. Customary mechanisms have failed to cope with external interests in land. The beaches that hitherto performed numerous customary functions have now been lost for scant return (Törhönen 1995). Lessons have now been learned and the situation has improved, but in the process customary tenure has been individualised in all valuable areas. Communal tenure now only exists in marginal, largely non-utilised, land. Similarly in Zimbabwe (Törhönen and Goodwin 1998, p. 98-99), communal tenure faces pressures owing to the increasing population and emerging commercialisation. It still exists, but its customary functions are being eroded by growing economic interests. Remote areas with low population densities are the least affected. Returning to Zanzibar, plantation-tenure in the $19^{\text {th }}$ century achieved a balance, albeit one based on slavery, where landlords with cash-crop trees and slaves farming and living under those trees both had adequate livelihoods. A crisis was experienced when external forces pushed for the abolishment of slavery. However, the peasant-landlord tenure that was adopted continued plantationtenure largely unchanged, and at its best enabled mutual benefits. The balance also depended on the lucrative clove-trade, and once markets declined landlords became indebted and pressure grew. Everyone suffered, with landlords losing their holdings to moneylenders and secondary land rights no longer being respected. One conclusion is that when pressure on customary tenure grew then secondary rights on land had little or no value. An important historical factor is that the insecure position of secondary right holders contributed to the 1964 revolution (Törhönen 1998a, p. 30-32), when the properties of all landlords were confiscated and tenure was reformed ${ }^{27}$.

While generally most customary land tenure is of a communal type, which evolves towards individualisation, the opposite has occurred in Finland (Jutikkala 1983, p. 7 - 9, Hyvönen 1982, 1998). Ancient Nordic countries were largely unoccupied, and when the population increased new families opened areas in forests and settled down in isolated farms with no village structure. The earliest written records, Scandinavian rural laws from 1100 - 1300, describe communities where families farmed individual fields. Hyvönen (1982, p. 51-52) describes how a cleared field was utilised for a period and thereafter was periodically left fallow. In the early stages land was subject to private interests only while it was used. Later the interest started to cover fallow periods and finally areas were demarcated regardless of utilisation. Communal tenure evolved only during the middle ages. A village structure became common both through voluntary grouping and through fragmentation caused by succession. There were many village tenure variations. Land seems to have been cultivated by villages as a whole but whether the land tenure or the farming technique was collective has been debated. Some communities were strong, forming belts of villages that linked large areas. In other areas private farms continued to be scattered in isolated units. Forests were held in various forms of joint tenure. Other resources were enjoyed through use-rights that were divided between community members.

During the past 400 years the Finnish land tenure evolution has been led by a series of land reforms aimed at increasing the government property revenue ${ }^{28}$. The most significant, the great consolidation (Saarenheimo 1983, p. 20-53) impacted crucially on land tenure. The vast, communally held forestlands that were, until the

\footnotetext{
${ }^{25}$ A very traditional type of African customary tenure with Arab/Islamic influence located in infertile coastal areas.

${ }^{26}$ A double-cropping system where landlords held clove trees and slaves picked cloves and lived on and held land for subsistence cultivation. Later, when slavery was abolished the custom continued with peasants and landlords.

${ }^{27}$ See Chapter 2.2.3.1 for the land reform mentioned.

${ }^{28}$ Historical Land Reforms in Finland are discussed in more depth in Chapter 2.2.3.
} 
late $19^{\text {th }}$ century, mainly used as land reserves, for firewood collection and hunting, were now apportioned between the landholders and the government. Individualisation of large forest areas for which there was no immediate use but where each new cleared field represented an investment for their owners, encouraged a pattern where a landless family might be allowed to clear forest for subsistence farming and housing in exchange for providing agricultural labour for the landholder. This became peasant tenure, which created a new social class. Previously, the government had restricted the subdivision of land for fear of decreasing revenue, but in 1743 it allowed the introduction of peasant farms, but not as individual properties. (Luomaaho T., Luoma-aho T. T. and Ojajärvi 1991, p. 64). The landowner owned, and paid taxes for, the entire area covering the peasant farms. In some cases rent was collected, depending on the contract made between the landholder and peasant (Luoma-aho T., Luoma-aho T. T. and Ojajärvi 1991, p. 64). Peasant tenure differs from lodging tenure of the same era ${ }^{29}$. The former was closer to a customary ${ }^{30}$ type of secondary right. It was beneficial for the landholder, who could relieve work peaks with additional labour and who had new fields cleared for him, and it was often also the best option available for many peasants, who got a home for the family and relative security without capital investment. Furthermore, it was beneficial for society in allowing early family-forming that boosted the growth of the population. So, in common with plantation tenure in Zanzibar, lodging tenure achieved a social balance based on mutual benefit. Peasant tenure was strongest at the beginning of the second half of the $19^{\text {th }}$ century, after which the commercial potential of forestlands was recognised. Landowners began to value their forest areas and consequently new peasant farms were no longer introduced. In the era of industrialisation, peasant tenure no longer proved an ideal arrangement. Land belonged to the landholder and the peasant's position was not clear-cut. Security was accordingly low, since there was a real risk of eviction. New agricultural techniques enabled landowners to cultivate larger areas than before, which created a desire to repossess peasant farms (Vitikainen 2002). Industrialisation also provided new options for peasants, and some were lured away from farming by the cash economy (Kokkonen 2002). Forestry, for example, started to require wage labour (Vitikainen 2002). Investments on peasant farms decreased since in the case of eviction landholders did not compensate peasants for improvements. Towards the end of the $19^{\text {th }}$ century, peasants started to demand permanent rights. The government responded by allowing subdivision ${ }^{31}$ and also by regulating the renting of rural land $\mathrm{d}^{32}$ including peasant tenure. This failed to convince the peasants, however, who went on to stage numerous strikes, in response to which evictions sometimes occurred. Renting regulations were adjusted again, but the tension persisted. Immediately after independence in 1917, the first Finnish government agreed in principal that peasant farms and lodgings would have to be privatised. A bill was sent to parliament, but the civil war ${ }^{33}$ halted it. Aspelund (1983 p. 224) points out that by the beginning of the war the bill had virtually been passed and therefore peasant tenure could not have been the cause of the clash. One cannot ignore the impact of overall political developments in Europe in general and Russia in particular. Still, peasant tenure was an issue that created tensions for a couple of decades.

Two continents, two very different countries, but one finds two quite similar land tenure cases. Can Zanzibari and Finnish land tenure evolutions be compared? Hardly, as such a comparison would disregard countless factors that emerge from history, culture and tradition. And yet the same conclusions were drawn separately from both cases: Customary land tenure, or tenure with clear primary and secondary rightholders, was able to provide mutual benefits in favourable circumstances but seemed to lose the ability when the economic situation changed drastically, at which time the position of secondary right-holders became very vulnerable and the resulting decline in security of tenure had a severe impact on social stability. External pressures are clear factors, but how about internal drivers of change? Libecap $(1989$, p. 116) has researched the motives behind changes in property right types and their distribution. He concluded that the

\footnotetext{
${ }^{29}$ In lodging tenure small cottages were rented for labourers. Peasants got their livelihood from the peasant farm, but lodgers from wages from the landholder's farm. (Luoma-aho T., Luoma-aho T. T. and Ojajärvi 1991, p. 64) say that these small, low-value, properties comprising a house and a small potato garden, of maximum two hectares altogether, were often owned by the lodgers.

${ }^{30}$ Although peasant farms were established based on a stipulated form of agreement (Kokkonen 2002, Vitikainen 2002) peasant tenure was not directly recognised by statute, making it comparable with a customary right.

31 1864. In 1895 the law on apportionment was passed (Luoma-aho T and Luoma-aho T. T. and Ojajärvi 1991, p. 64).

${ }^{32}$ See Hyvönen 1998, p. 122-124 for the settlement legislation in the $20^{\text {th }}$ century.

${ }^{33}$ The government (whites) won a bloody war over the labour-oriented reds (including many peasants) in a couple of months.
} 
rational use of resources and economic growth are not engines for change, but rather the expected gains in net private benefits. He sees the distribution of property rights as an issue behind conflicts. This proved correct in Zanzibar and in Finland, but only after the mutual-benefit equilibrium was disturbed.

\subsubsection{Land Reform}

Land tenure evolution can be accelerated by land reform, which I define as a man-made change to land tenure usually aimed at changing land distribution. The Finnish land tenure evolution, a catalogue of land reforms, provides the land reform case study for this research. These land reforms, with the exception of forest-ownership, aimed at land use classification and rationalisation, and only in the last century crisissituation did reforms alter land distribution. Little is known about the ancient land reforms in Finland (Hyvönen 1982, p. 90-94, 1998, p. 104-108) but repeating housing and cultivation patterns are too widespread to have emerged without some man-made exercise. Reforms followed population growth as land became scarce. The first pattern identified is block division ${ }^{34}$, which divided up villages into private and public areas, and separated individual parcels. Critics say that block division resulted from the clearing of land rather than of land reform. Documentation on later reforms indicates that villages were organised either according to ancient or to back-land division. Ancient division seemed to target houses and fields, and backland division the untouched remote areas. Both were common and have been researched in Sweden ${ }^{35}$, but their spread in Finland is unclear.

The driving force of known land reforms in Finland has been taxation ${ }^{36}$, which became systematic in the Middle Ages. Villages were to hand out a share of their produce to the Crown. The amounts demanded per area grew and the burden had to be apportioned between farms. This led to strip division (Jutikkala $1983 \mathrm{p}$. 10-19). This happened mainly in Western Finland ${ }^{37}$ and targeted both untouched and anciently divided villages. Allocation of strips followed a farm's tax share and this in turn, sometimes at least, reflected the farm's residential parcel size. Forests ${ }^{38}$ were left as village lands (Luoma-aho E. J. 1991, p. 132). Simple methods were used for survey and demarcation (Hyvönen 1982, p. 95-96, 1998 p. 110) allowing farmers themselves to classify and divide land into the narrow strips. Farmers co-operated in order to share the taxation burden equitably and also to clarify and secure the land distribution (Vitikainen 2002). The formal society we know now was only in its infancy, and perhaps farmers sought security via state recognition of holdings (Kokkonen 2002).

Ylikangas (2000, p. 48-61), who has researched crime development in Finland, points out that insecurity of tenure and ambiguity in land distribution caused by the weak execution of authoritative and legal powers, were the primary sources of rural violence ${ }^{39}$ in the $15^{\text {th }}, 16^{\text {th }}$ and $17^{\text {th }}$ centuries. Lands were physically defended and acquired, rights violated and weak holders ${ }^{40}$ struggled to keep their holdings (p. 55). Courts handled violent land disputes, but rulings were weakly enforced. Strip-division boosted disputes by creating narrow, poorly demarcated strips, with a high potential for trespassing (p. 56). By the middle of $18^{\text {th }}$ century strip-division was seen as hindering agricultural development. A farm could consist of more than a dozen narrow strips, which were cultivated collectively and therefore required unanimous decisions. The joint ownership of forests potentially lessened forest-cover since the slash-and-burn technique was commonly used $^{41}$. Finally, insufficiently surveyed strip-divisions caused a major tax burden for some while others were free passengers.

A solution was sought in the great consolidation (Saarenheimo 1983, p. 20-53) i.e. via the introduction of big, individually-cultivated parcels for increased agricultural production and population growth (Hyvönen

\footnotetext{
${ }^{34}$ Block Division prevailed in Eastern Finland.

${ }^{35}$ Finland was a part of Sweden from 1155 until 1809, when it became autonomous in the Russian Empire. Finland became independent on 6 December 1917.

${ }^{36}$ Governmental taxes on agriculture were introduced in 1250's and church taxes even earlier (Hyvönen 1982, p. 69).

${ }^{37}$ The Finnish strip-division recordings date from 1332 until the $18^{\text {th }}$ century (Hyvönen 1982, p. 94-95, 1998 p. 109).

${ }^{38}$ Used at the time for tar production, as a general material resource and as a field land reserve.

${ }^{39}$ Also Deininger and Binswanger (1998) see asset distribution and social exclusion as causes for rural violence.

${ }^{40}$ Ylikangas mentions widows.

${ }^{41}$ See about tar production in Luoma-aho E. J. 1991, p. 134-135.
} 
1982, p. 94, 96-97, 1998 p. 109, 111). This was a western European phenomenon, with the Swedish/Finnish being one of the earliest examples ${ }^{42}$. Hyvönen points out that neither strip-division nor the great consolidation were desired by the population, but were imposed by the foreign ruler. The government assumed a right to launch the great consolidation in areas to be surveyed for taxation ${ }^{43}$. The steps were valuation, classification, consolidation and unification of units to between one and several parcels per landholder. The quality of land correlated with size of allocations. Farmers were actually to benefit through the improved farming made possible, but the apparent connection with taxation meant that the great consolidation was regarded as being solely in the government's interest. This, coupled with a reluctance to change, a mistrust of valuation results, a fear that consolidation served only the interests of the wealthy, and finally the surveying costs involved ${ }^{44}$ caused resistance. The government persisted however, and by the end of the $18^{\text {th }}$ century all resistance had dried up. The government introduced land distribution tribunals, consisting of locally trusted persons and a knowledgeable chair (Karanko 1983, p. 390), to resolve disputes. The only appeal was to the King, which made settlements very effective. By the independence declaration of 1917 , most of the country had been consolidated ${ }^{45}$. It had taken one-and-a-half centuries to survey, classify, consolidate and reallocate most of the Finnish land parcels. Even so, a good half-century was spent taking the task to completion ${ }^{46}$.

Results of the great consolidation have been debated. Land tenure was unified, forests for the first time were apportioned between farmers and the government, all land was now held in freehold ${ }^{47}$ and administrative boundaries were demarcated (Ojanperä 1999 p. 13). Ylikangas $\left(2000\right.$, p. 61) suggests that $17^{\text {th }}$ century improvements in cadastral surveys and the strengthening of the legal system over property right questions improved security of tenure, which significantly lessened rural violence. The great consolidation could not have played a role, as the reduction occurred before it started (p. 59). Still, it was the great consolidation that introduced finality in land tenure and irreversibly secured land ownership (Kokkonen 2002). In other words, law and order reached grassroots level. As an exception, the great consolidation altered land distribution once the policy of surplus acquisition was adopted in the late $18^{\text {th }}$ century. Forestlands that exceeded a regional maximum per farm ${ }^{48}$ were appropriated by the government (Saarenheimo 1983, Luoma-aho and Ojajärvi 1991, Hyvönen 1982, p. 101-102, 1998, p. 115-117, Ojanperä 1999, p. 14-15). These State forests were taken for a settlement program that was intended to relieve landlessness and increase population. The government saw this as the mobilisation of an under-utilised potential. Landholders ${ }^{49}$ accepted the acquisitions relatively calmly, apparently because there was a surplus of forestland ${ }^{50}$ that was not yet commercially utilised. Also, the sense of ownership of remote forests was not strong. In addition, the government interpreted size limits flexibly. For example a larger area was made available if a landholder agreed to increased taxes, and low-value lands could be acquired for a low or even zero tax-increase. Naturally the temptation was high for a valuer (a low-paid surveyor) to accept a benefit and issue a valuation favourable to the landowner. In the end the government had to demand a second opinion every time an additional land area was handed over without a tax increase.

The great consolidation improved cultivation, but many farms were still uneconomically scattered and shaped. Also forests came to be held in long narrow strips, which proved uneconomical. There is still a debate on whether the privatisation of forests had an effect on husbandry. It is likely to have hindered the destructive use of forests, but it is unclear what extent and significance this bears in relation to other issues such as the increased value of forests. Industrialisation certainly benefited, since forest privatisation enabled the emerging pulp and paper industry to acquire wood effectively. The surplus acquisition policy has not been shown to have significantly impacted on population growth, but it certainly made the government a

\footnotetext{
${ }^{42}$ Started in 1757 (Luoma-aho and Ojajärvi 1991, p. 45, Hyvönen 1982 p. 97, 1998 p. 112).

${ }^{43}$ In Sweden, the great consolidation required a landholder's application in order to begin (Ojanperä 1999 p. 13)

${ }^{44}$ Surveyors got a basic salary from the Crown (Vitikainen 2002), but landholders supplemented this during the work period.

${ }^{45}$ In 1809 Finland gained autonomy from Russia, but the great consolidation continued.

${ }^{46}$ Last ones in Lapland in the 1960's (Luoma-aho and Ojajärvi, 1991 p. 45, Hyvönen 1982, p. 97, 1998 p. 112).

${ }^{47}$ State lands in Finland are subject to the same regulations as private lands; they are just owned by the state.

${ }^{48}$ The local maximum sizes varied a lot from one area to another based on actual utilisation of lands in the area.

${ }^{49}$ Hyvönen mentions that Crown/Church aristocrats had exemptions, but Ojanperä saw them as most heavily affected.

${ }^{50}$ Vitikainen (2002) points out that people saw the possibility of new settlements as a positive thing.
} 
huge forest owner in the more remote areas (Luoma-aho and Ojajärvi, 1991 p. 45, Ojanperä 1999 p. 15), a situation that has persisted until today. The settlement programme did not work well, with land in many cases circling back to its original owner. Socially, as individualisation progressed village connections were weakened in some areas while in others no significant changes took place. Land ownership strengthened and the landless came under the direct control of owners. This had important consequences, such as peasant tenure, which created a new social class that was to change society ${ }^{51}$. Ojanperä (1999 p. 18) concludes that, through the great consolidation, society de facto prepared for the transition from subsistence farming to cash crop agriculture and industrialisation.

As soon as the great consolidation finished, and even while it was still under way, modification was needed to improve the results. It had not been effective everywhere, and large areas still suffered from a fragmented parcel structure. Consequently, the new consolidation (Saarenheimo 1983, p. 53-62) started in the middle of $19^{\text {th }}$ century ${ }^{52}$. Originally it was a voluntary, rather cumbersome process, which would start only in response to a high-level governmental decision or by a unanimous decision of acceptance and cost sharing by all landholders. In the late $19^{\text {th }}$ century the process was streamlined and the costs were borne by the government, which boosted it (Ojanperä 1999, p. 19-20). The idea was to reposition fields and farm centres in a more rational pattern for faster commuting and improved access to arable and grazing land. Farm centres were sometimes moved, something that had rarely occurred in the great consolidation. Initially the government subsidised and financed farm centre moves, and later infrastructure improvements also (Vitikainen 1999, p. 39 ). By the mid $20^{\text {th }}$ century the new consolidation had become heavily subsidised. Economically, new consolidation proved beneficial. Socially, it effectively changed village society into one of private and dispersed farms. Critics note losses in countryside ambience and the sense of togetherness. They also see working costs as growing when group-work lessened, and take consolidation as a hindrance to the distribution of infrastructure. The counter criticism maintains that village society would have fallen apart anyway as subsistence farming was replaced by commercial farming. Saarenheimo (1983) points out that families also moved out from villages in areas that did not undergo new consolidation. By the $20^{\text {th }}$ century the new consolidation had become popular, although some disputes had occurred. New consolidations have continued up to the present day, although with changing aims and form.

Three major land reforms have shaped Finnish land tenure. These reforms originated from taxation and aimed to improve farming, but they also introduced law and order down to grassroots level, the great consolidation in particular. The land tenure evolution has been remarkably structured and controlled. Even when the government de facto confiscated large areas of forest no real resistance was noted. Vitikainen (2002) suggests that the success of reforms was enabled by strong community participation and control. Apparently the reforms were carried out relatively fairly and formal tenure structures were seen to be more secure than informal ones. It was only peasant tenure that created serious social unrest ${ }^{53}$, which later led to a land distribution reform.

\subsubsection{Land Distribution Reforms}

Finnish peasant tenure was reformed after the civil war (Aspelund 1983). The law that had been held up by the war was quickly passed thereafter, enabling peasants to buy out their farms for low fees ${ }^{54}$. If a voluntary sale was not reached, an acquisition order was made out and the farm was allocated to the peasant against a long payback. This was socially significant. Peasants became farmers i.e. landowners and private entrepreneurs, in contrast with their previous status as labour force with an insecure future and tenure ${ }^{55}$. In 1922 a new privatisation law created a right for every landless Finnish citizen with the necessary farming skills to acquire farmland. The means of acquisition were the same as for peasants. These reforms lessened tensions and succeeded in stabilising the young independence. The small farms so formed survived well and the farming families managed slowly to improve their living standard. The original landholders, who had lost

\footnotetext{
${ }^{51}$ Peasant tenure was explored in the previous Chapter.

${ }^{52}$ Already by the beginning of the $19^{\text {th }}$ Century in Sweden.

${ }^{53}$ Pre-independence peasant tenure is described in Chapter 2.2.2.

${ }^{54}$ The price level used was backdated four years.

${ }^{55}$ Also industrialisation progressed providing alternative income opportunities for the landless population.
} 
their temporary labour, started to invest in agricultural machinery, which improved farming techniques. Agricultural production grew significantly during the following decades.

The post-revolution land reform in Zanzibar (Törhönen 1998a, p. 33-54, 88-89), which targeted plantation tenure, can be compared to the peasant tenure reform in Finland. The Zanzibari reform followed the socialist ideology of confiscating and distributing landlords' holdings to the peasants, who were granted use rights to land. The reform aimed at the lucrative clove trees rather than the land itself, and the new tenure regime restricted land use to clove farming only. Over the following decades the clove trade became much less lucrative, but the restrictions remained. In addition, transfers were not allowed and inheritance required a new granting process. All this has fuelled informal, non-registered transactions and inheritance. The distributed parcels have become illiquid, insecure holdings tied to an uneconomical land use. They have become unproductive. On the contrary, less valuable lands that were not redistributed at the time of the revolution are now held in a kind of freehold ${ }^{56}$ that allows flexible land use and inheritance and may be freely transferred. The land that was regulated in detail has become worse utilised than that left to evolve naturally.

\subsubsection{Refugee Settlement}

The new land distribution challenge occurred after the Winter War in 1940, at which time Finland had to hand over or rent parts of its territory to the Soviet Union (Suomaa 1983) and the population of those areas had to be resettled at once to other parts of the country. A law was passed ${ }^{57}$ and over 450000 people were resettled. Refugee families were entitled to land and housing of a similar size to what they had lost. Professional commissions were created for fast-settlement and a court of appeal was set up to arbitrate disputes. Land was acquired primarily from public sources (the state, municipalities, church) and idle private farms, with land from active landholders only being acquired as a last resort (roughly a quarter of the acquisitions) (Suomaa 1983, p. 281). Compensation was based on market value before the war.

The second war between Finland and the Soviet Union occurred in 1941. Areas that had been lost were recaptured and 70-90\% of refugees returned to their homes (Laitinen 1996, p. 239). However, after the peace agreement in 1944 all of these areas and more were handed over again, and the refugee settlement exercise had to be repeated (Åberg 1983, Kantee 1983). This time war invalids, war orphans, war veterans and other minor groups were also entitled to allocations ${ }^{58}$. All rural refugees ${ }^{59}$ from Karelia ${ }^{60}$ were also settled, and in total 101000 new farms ${ }^{61} / 62$ were created (Laitinen 1996, p. 239-240). Why was land given to other than refugees (Laitinen 1996, p. 244)? Those were tough times, and the desire for land, a means of stability and security, was high. Government, whose aim for self-sufficiency in farm produce was endangered by the war and the lost Karelian fields, wanted to open up new fields for cultivation. When the refugees of the first war returned to Karelia, the government, with many settlement farms now on its hands, made announcements that war veterans would be allocated land. These promises had to be met even though the size of Finland had decreased $^{63}$. The procedures for acquisition, reallocation, and dispute settlement were substantially the same as previously. The real properties thus formed were intended for housing, farming or fishing. The compensation value was fixed to the 1944 price level, which was soon eroded by inflation. This was compensated for to some extent by offering taxation relief to landowners who lost land. Recipients paid for their allocations, but refugees only paid the balance between the value of the lost and the allocated farm. They were also given government loans for farm development. Allocated lands could only be transferred to

\footnotetext{
${ }^{56}$ Shamba land tenure $=$ the government owns all lands but improvements are held and transferred freely.

${ }^{57}$ See Hyvönen 1998, p. 122-124 for the settlement legislation in the $20^{\text {th }}$ century.

${ }^{58} 165000$ applications were made (Åberg 1983). Laitinen (1996 p. 240) says that the number was 149000.

59230000 .

${ }^{60}$ As a point of personal interest, the 410000 Karelian refugees (Laitinen 1996) included my father Niilo Törhönen, born in Sortavala in 1933.

${ }^{61}$ The Karelian refugees got $40 \%$ of new farms, $60 \%$ went to other groups.

${ }^{62}$ Apart from newly allocated farms, 34000 smallholder-war veterans received additional land areas.

${ }^{63}$ Refugees and demobilised war veterans were seen as a potential source of instability. The policy was to provide them quickly with a place and meaningful work; a piece of land did the job perfectly (Kokkonen 2002).
} 
another eligible person, but once paid for (or after five years of occupancy and in some cases after twenty years) they became freely transferable.

Resettlement was important both for stability and for restoring the refugees' livelihoods. Some landholders complained about acquisition amounts but the nation, unified by the war, was generally in favour and no serious tensions arose. Rural infrastructure was improved as many roads were built for the new settlements. Agriculturalists warned about the reduced average farm sizes ${ }^{64}$, but contrary to their fears there was soon an overproduction of food (Kantee 1983, p. 319, Laitinen 1996, p. 245-246). Less than half of the new farms were intended to provide a full livelihood, but rather to enable part-time farming, and many were engaged in semi-subsistence farming up to the 1960's (Laitinen 1996, p. 242 - 249), which provided a basic living adequate for those lean times. The resettlement drive caused already rare large farms practically to vanish, and family farming became the rule (Hyvönen 1998, p. 123). Laitinen (1996, p. 251) says that given the low number of large farms to start with, the structural change was not significant. During the following decades, the average farm size grew owing to increased urbanisation and industrialisation. A typical progression is described by Luoma-aho E. J. (1991, p. 137); $98 \%$ of the population of his native village in the SouthWestern Finland lived directly from agriculture in 1930's, but in 1986 this had fallen to about five percent. Resettlement, among other factors, increased farm numbers to an unsustainable level for an EU country of the $21^{\text {st }}$ century (Laitinen 1996, p. 256). Still, Laitinen and others say that settlement was unavoidable. Apart from the agricultural successes and setbacks, it provided social status and security to a large sector of the population recovering from the wars. Contrary to the recent World Bank conclusion that re-distributive land reforms have never been very successful (Deininger and Binswanger 1998), Finland did in fact benefit from its crisis-situation reforms ${ }^{65}$.

\subsubsection{Indigenous Refugee Settlement}

After the wars Finland also had to settle an indigenous refugee group, the Skolt-Sami (Poutanen 1983, p. 332-333). Most of the Skolt-Sami had lived in their native area in the Soviet Union, but a few hundred ${ }^{66}$ had lived in Finnish territory that was handed over (Linkola and Sammallahti 1995, p. 53-54, p. 38, 52). Their land tenure had consisted of demarcated areas for winter and summer villages, and it was based, at least in the 1940's, on private family tenure (Linkola and Sammallahti 1995, p. 53-54, Sergejeva 1995, p. 67-68). Ownership of land was vested in the village as a whole, but individuals held land areas permanently for various uses. The village assembly had the power to change land use rights (Wirilander 2001, p. 2-8). Old sale documents, wills and dispute-settlement documents for land and natural resource rights have survived (Mikkola 1941 p. 22-32), supporting the conclusion that the Skolt-Sami had an understanding of ownership/permanent use-rights of natural resources, and their value and transferability ${ }^{67}$. Land-use rights were inherited and used as collateral, which resulted in transfers of some traditional areas. The Skolt-Sami refugees were settled mainly in two areas ${ }^{68}$ of Lapland (Terho 2001, p. 51). The biggest group, a village, was located in a remote arctic wilderness, isolated from other populations. Others went to more populated areas. The Skolt-Sami were not dealt with like other rural refugees. Several laws were passed to make provision for their land tenure arrangements. Before the war, the Skolt-Sami had used huge land areas for reindeer herding, hunting and fishing. The loss both of these and their villages were compensated for with cottages constructed on 3 ha land parcels coupled with a right to use certain state land for "reindeer herding, fishing, hunting and livestock rearing" (Hyvärinen 1995, p. 23, Wirilander 2001, p. $9^{69}$ ), and also for firewood collection etc. However, other groups also had access to identical rights in same areas. Ownership of the cottages was granted, but transfer was restricted. The Skolt-Sami became tied to their parcels (Poutanen 1983, p. 332). Furthermore, although the Skolt-Sami had been accustomed to tight village structures in the past, the cottages were spread out and isolated. This negatively affected communication (Semenoja 1995, p. 82 , Terho 2001, p. 52). In land use matters, the village assembly lost its power to the government. Semenoja

\footnotetext{
${ }^{64}$ In 1941 the average field size per farm was 9,2 ha and in 1959 it was 7,9 ha (Laitinen 1996, p. 251).

${ }^{65}$ A slight setback has been that the Karelian refugees have largely been unable to pass the Karelian dialect and cultural heritage to subsequent generations. Their heirs have integrated with the mainstream population.

${ }^{66}$ According to Semenoja (1995, p. 82) there were 443 Skolt-Sami refugees from the handed-over Petsamo Province.

${ }^{67}$ This issue is explored further in Wirilander 2001, p. 17-19.

${ }^{68} 267$ to Näätämö, 140 to Nellimö, and a few others elsewhere.

${ }^{69}$ Actually allowed only sheds etc. for fishing (Wirilander 2001, p. 9-10). The fishing right was issued only in 1981.
} 
estimates that the new areas were less fruitful than the areas that had been lost. The cottages were modest and generally too small for large Skolt-Sami families (Terho 2001, p. 53). An account written six years after resettlement describes how many of the younger generation had already moved to the towns for work (Terho 2001, p. 58). In general the resettlement was difficult, and although government provided various subsidies some anger about living conditions has been recorded (Terho 2001, p. 56-59). Nevertheless, the main settlement area was close to previous Skolt-Sami areas, and although many would have preferred to return home they accepted the situation without protest (Linkola and Sammallahti 1995, p. 55). At the end of 1960 's, the Skolt-Sami laws ${ }^{70}$ were revised owing to problems in livelihood and equality in comparison with the mainstream population (Wirilander 2001, p. 11). The Skolt-Sami gained the right to hand over their parcels to the government ${ }^{71}$ for fair compensation, after which they would be allocated either a residential parcel or a private reindeer farm ${ }^{72}$. By the 1970's the Skolt-Sami had gained the same status as other reindeer-herders (Terho 2001, p. 60).

Presently, few old Skolt-Sami live in the resettled areas. Their customary livelihood has not entirely vanished, but new generations have been integrated with the mainstream population (Metropolitan Leo 1995, p. 61-64). Critics say, however, that customs have been completely reformed (Semenoja 1995, p. 82-83). Pressures on this minority have been strong ${ }^{73}$ (Semenoja 1995, p. 83-87). The Skolt-Sami language as a mother tongue, and tight Skolt-Sami societies have now vanished. Their customs did not survive the less favourable conditions. Reindeer herding is now the source of income for only $10 \%{ }^{74}$, and hunting, fishing and lamb-farming have only marginal significance for Skolt-Sami livelihoods ${ }^{75}$. Berry picking has become an important additional income source. Unemployment is high and a quarter of the population has left the area permanently. The culture is in danger of disappearing altogether. The Skolt-Sami refugee resettlement and their land tenure arrangements show how difficult it is to preserve a culture and its customary tenure from the outside, not to mention transferring it to a different location. This research suggests that the Finnish government did not study the Skolt-Sami land tenure and culture sufficiently carefully, and introduced new customs that reflected only partially the ancient Skolt-Sami tradition ${ }^{76}$. It is not feasible to tie groups to land while restricting the land use, something that also proved to be the case in Zanzibar ${ }^{77}$. But can the weakened culture be blamed on resettlement? I stopped short of verifying that. Skolt-Sami customs had been weakening for a long time before the resettlement (Wirilander 2001, p. 2-8). And during recent decades most Finns have moved to cities, thereby transforming their lifestyles, so why not the Skolt-Sami? Inevitably such a restricted, government controlled, tenure did not have a positive impact on the survival of Skolt-Sami customs. Flexibility in land use and transfer, which all other settlers benefited from, would have increased possibilities for accommodating new initiatives. Also, World Bank evidence calls for caution to be exercised towards any socially justified restrictive land market measures, because success has been rare (Deininger and Binswanger 1998) ${ }^{78}$.

\subsection{Land Registration}

Land and property registration systems reflect a nation's culture, history, legal tradition, level of development and politics just as much as do its land tenure arrangements. While accepting that each system is unique, their classification according to a few main theories helps to structure research. Firstly, there are

\footnotetext{
${ }^{70}$ See a detailed record on Skolt-Sami legislation in Wirilander 2001.

${ }^{71} \mathrm{Or}$ in cases of joint ownership the share was to be sold to other shareowner(s).

72 About 70 Skolt-Sami farms were established in 1947-49 (Terho 1995, p. 51) and about 70 residential parcels in the 1970's (Wirilander 2001, p. 12). Later, allocation rights became accessible also to Skolt-Sami other than (partial) settlement farm holders, but these were seldom taken up as new generations moved away from the area.

${ }^{73}$ The Skolt-Sami are in a minority among Finns and among other Sami, differing from others both in language and religion.

${ }^{74}$ Wirilander (2001, p. 13) shows that despite the possibility, only a few reindeer farms were formed for the Skolt-Sami.

${ }^{75}$ Only $23 \%$ of Skolt-Sami in the area in 1991 got income from reindeers, fishing and berries (Wirilander 2001 p.15).

${ }^{76}$ The renewed Skolt-Sami law of 1995, as the first Finnish statute (!), recognised the Skolt-Sami traditional village assemblies and other customary administration (Wirilander 2001, p. 17).

${ }^{77}$ In Chapter 2.2.3.1.

${ }^{78}$ The WB presents a voluntary, community-managed reform as a potential way of reducing the problems of asset distribution and social exclusion.
} 
fiscal and legal land registers ${ }^{79}$. The legal group consists of deeds registration ${ }^{80}$, where documents in the register are the evidence of title, and title registration, where mostly the register itself serves as the primary evidence. In the deeds system, a registered deed takes priority over an unregistered or a subsequent deed, and in some systems unregistered deeds are not accepted as proof of title. A similar principle of recognising only registered interests has outlawed most land holdings in Zanzibar and in Cambodia ${ }^{81}$. Legal protection covers a landholder only when the holdings have been registered, and by far the majority are not (Törhönen 1998a, p. 92, Törhönen 2001, p. 412, 414). However, as a theory, the registration of a deed does not affect its legal status, it is merely stored. Adjudication is repeated for every conveyance through the entire conveyance chain. Lawyers and surveyors are involved, duplication takes place and unit costs rise. But from the point of view of government the register is cheap to maintain. A comparative analysis of the Zanzibar land register development options showed that in low-resource conditions a gradually-improved ${ }^{82}$, sporadic ${ }^{83}$, deeds registry system was more feasible than anything more advanced and all-embracing ${ }^{84}$ (Törhönen 1998b, p. 114-118). The security that deeds registries provide has often been adequate. Bogaerts and Zevenbergen (2001 p. 330) point out that a register of deeds does not mean that the land registration or land administration system is improper or untrustworthy ${ }^{85}$. While in developing countries the deeds system is often the most feasible solution, it usually serves only the better-off of the population as in Zanzibar (Törhönen 1998b, p. 113-114) and in Cambodia (Törhönen 2001, p. 410, 414) ${ }^{86}$.

Title registration was introduced to overcome the problems associated with deeds registration (Simpson 1976, p. 14). Its purpose was to simplify and secure conveyancing, avoid repetition and increase efficiency. Title registration is based on a state guarantee of title. Finality is thus ensured, and repeated adjudication unnecessary ${ }^{87}$. As previously explored, any absolute guarantee of title is problematic in a developing world context. Theoretically, since only an entry to the register can convey title, a title register needs always to be updated, which in developing countries is often likely to remain in the realms of theory. In Zanzibar, for instance, the land register ${ }^{88}$ contained data on granted land that was neither to be sold nor altered, but while the register showed the parcels to be intact, field research often revealed them to be subdivided (Törhönen 1998a, p. 37). A title may live its own life distanced from reality. Yet, even after years of unrecorded conveyances and multi-layer tenure, only titleholders have legal protection. An outdated title registry, instead of securing title may disregard conveyances and outlaw contracting parties. The conclusion is that a title system should not be introduced if there is a fear that it will not be implemented fully. Originally, title registration systems were not designed to support land management or property taxation ${ }^{89}$, they did not contain registry maps and no data-sharing was planned. Although repeated adjudication was avoided, the lack of maps meant resurveying for transfers, making them still more cumbersome and expensive. The compulsory professional tasks in both deed and title registration systems have resulted in costly conveyances, which together with informal fees make registration unfeasible for most inhabitants of developing countries. In Zanzibar, an urban land register covers only government allocated parcels and the deeds register for rural areas only exists in name (Törhönen 1998a, p. 53, 90, 92). In Cambodia, despite the public desire $^{90}$ for registration, the register covers only about ten percent of parcels. Registration is too

\footnotetext{
${ }^{79}$ The legal registers are often called land registers and fiscal registers cadastres, but many variations can be found.

${ }^{80}$ For detailed theory see Simpson (p. 91-109).

${ }^{81}$ See Chapter 2.2.

${ }^{82}$ For example, parcel-based, computerised and boosted by legislative measures that promote updating and coverage.

${ }^{83}$ See Chapter 2.3.1 for sporadic first-registration.

${ }^{84}$ The expected gains from a comprehensive title system were a multiple of those for a sporadic deed system, but the cost estimate and expected rate of complementation (without external funding) drastically lessened the expected benefits. The result of a poorly reformed system and multi-layer tenure anarchy (Chapter 2.2) was not considered. That aside, a new analysis would strengthen the deed option's position as the most feasible solution. A systematically introduced title system would require external inputs for living up to its potential. See also Chapter 2.3.1 for firstregistration.

${ }^{85}$ The Dutch integrated register of deeds and cadastre has proved $99 \%$ reliable (Bogaerts and Zevenbergen 2001).

${ }^{86}$ See the next Chapter for the problems of first-registration in this regard.

${ }^{87}$ Some interests on land may not be registered; the inspection of land is not always totally avoided (for example leases). Overriding interests are problematic since title is meant to be absolute (Simpson 1976, p. 18).

${ }^{88}$ Though it was not a question of absolute title, the case is comparable.

${ }^{89}$ For example, in the case of England the records were until quite recently only accessible to the legal interest holders.

${ }^{90}$ In 1992 in Cambodia, a governmental campaign attracted 4,5 million first-registration claims.
} 
expensive for the majority of the poor (Törhönen 2001, p. 414). If an official land administration system fails, another will fill the gap. In Zimbabwe, the village elders had data superior to the authorities on land holdings and management (Törhönen and Goodwin 1998, p. 98-99). It is noted that as title systems have developed, the need for external support has lessened and feasibility and data sharing have improved ${ }^{91}$.

A fiscal register records data in cadastres ${ }^{92}$ established for taxation purposes (Simpson 1976, 110-124, Dale \& Binns 1995, p. 20). In developing countries, a fear of taxation ${ }^{93}$ may result in non-comprehensive or outdated cadastres (Dale \& Binns 1995). In Cambodia, transactions are often not registered in order to avoid transfer tax (Törhönen 2001, p. 410-411). Some cadastres have no direct link with taxation. A modern definition accommodates multiple objectives, taking cadastre to be a general term denoting official land records, which may be further classified at least into legal and fiscal cadastres (FIG 1995). The adoption of the term "legal cadastre" narrowed the line between the land register and the cadastre. Bogaerts and Zevenbergen (2001, p. 330-331) tried to establish which type of cadastral system, fiscal or legal, is more beneficial to a country, but concluded that it is not so much the type as the quality that matters, and fiscal cadastres have provided a good basis for legal cadastres. Such a comparison is hardly fruitful, however, as cadastres have evolved over time and have been modified for a vast number of purposes, as in the case of Finland (below). The rationale behind a type of cadastre cannot be divorced from its time and place. Today, cadastres are extolled as being feasible, and concerns have been raised on data misuse and the violating of private interests, which are a real threat in non-democratic conditions (FIG 1995). Cadastres have often been too expensive to establish, to operate and to maintain, in particular in developing countries. In Europe the cadastral evolution started modestly, owing to low resources, and it progressed slowly as resources improved (Larsson 1991, p. 38-40). Europe also has examples where poor maintenance has caused records to become practically useless. Larsson concludes that a cadastre should cover its target area, be simple, well-constructed and cheap otherwise it may fail to attract finance for maintenance.

In Finland, the earliest attempts at land registration were to serve taxation (Heikkilä 1983). Church taxes based on family size and agricultural production date back to the $11^{\text {th }}$ century, and the government took these over partially in the middle of $13^{\text {th }}$ century. The first systematically collected tax-duty record, the land book, was established in $1524^{94}$. In the $17^{\text {th }}$ century, tax-shares started to reflect landholding sizes, and the key data became the real property name instead of the owner (Hyvönen 1982, p. 70-71, 1998, p. 138-139). Until the beginning of $19^{\text {th }}$ century property taxation was still the main revenue generator, but in the beginning of $20^{\text {th }}$ century it became marginal and was cancelled. The land book became outdated and served no purpose and in 1937 it was terminated. In parallel to the land book, the National Land Survey had been ordered to maintain a provincial index record on the land book data in 1812 (Heikkilä 1983, Hyvönen 1982, p. 119-120, 1998, p. 140). In 1848 a law stipulated the maintenance of a comprehensive land book register including all public and private properties. First attempts met with limited success and it was only in 1887 that the first comprehensive cadastre was created (Heikkilä 1983, Hyvönen 1982, p. 120, 1998, p. 140-141). It was a public, parcel register ${ }^{95}$, a principle that still exists today. There was never a tangible connection between the cadastre and taxation, and there is still none today. The cities that grew up on Crown lands remained outside of the property system until the 1930's, when individualised city properties were allowed (Heikkilä 1983, Hyvönen 1982, p. 140-149, 1998, p. 140). However, the cadastre did not cover public forests, nature reserves and many types of historical tenure. The cadastre did not embody state liability; only civil servants' actions were liable but not the content of the register (Hyvönen, 1982 p. 121). A new initiative started in the 1970's and was implemented in two decades. The cadastre was to cover all properties in all areas and was to be

\footnotetext{
${ }^{91}$ The Australian title registration system, the Torrens system, deserves to be mentioned separately (Larsson 1991, p. 44-49, Simpson 1976, p. 68-90, Stein and Stone 1991). It has spread widely. Conveyances take place in the register following standard forms and procedures. The difference from the basic system of title registration is that the Torrens register and the title, apart from the comprehensive legal data, contains also a detailed description of land. Transactions are based on the registered data only; the data is useful, and used, beyond titling.

92 The first successful cadastre, was introduced by Napoleon to France (Larsson 1991, p. 19-22). It spread to colonies outside the "Anglo-Saxon" world, which mainly have legal registers. Still, to this day the French cadastre is a fiscal record, which is not linked to legal registers (Maurin 1992).

${ }^{93}$ This may not be a just fear. De Soto (2000, p. 73) shows how extralegal fees potentially account for more than legal.

${ }^{94}$ The oldest recordings in Finland date back to 1539.

${ }^{95}$ Displaying parcels' physical and legal nature, boundary data, easements, map numbers and the archived documents.
} 
based on modern technology ${ }^{96}$. In 1985, rural and city cadastres ${ }^{97}$ were legally unified (Hyvönen, 1998 p. 153).

European land administration structures often have both fiscal and legal records (Bogaerts and Zevenbergen 2001, p. 327-329). The Finnish title register was established in the 1930's and was expanded to cover mortgages in the 1950's (Hyvönen, 1998 p. 142). The Ministry of Justice keeps the title and mortgage register ${ }^{98}$ linked to the cadastre ${ }^{99}$. Today, many European land administration departments, apart from traditional tasks, distribute land information for a vast number of purposes to a variety of clients (Larsson, 1991 p. 29-37). Cadastres have rapidly advanced both in automation and utilisation of Internet applications. Finnish land administration was reformed in the late nineties ${ }^{100}$. Hyvönen (1998, p. 34-51) summarises the leading principles of Finnish land registration (legislation), which reflect the Finnish constitutional equality and impartiality. The liability of the keepers of the register was increased (Hyvönen, 2001 p. 1), but titles were not guaranteed other than by the state guarantee on authoritative actions ${ }^{101}$. Public liability is enshrined at a high level, because private property is protected by the constitution ${ }^{102}$ (Hyvönen 1998, p. 188-212). Presently, land registration is based on three components: the cadastral index map ${ }^{103}$, the cadastre and the title and mortgage register. The same components have existed since the end of $19^{\text {th }}$ century, but now they are technically integrated and unified (Hyvönen 1998, p. 1-51). The cadastral index map still has no legal force, despite initiatives to integrate it with the cadastre ${ }^{104}$ (Hyvönen, 1982, p. 127, 1998 p. 164-165). Recently, land record integration has been rapid and all data is now in digital form and is interlinked. Parallel and duplicated functions have been removed ${ }^{105}$. Despite formal dualism in land registration, functions are merged and dualism hidden. In addition, the system ${ }^{106}$ is linked to many authorities such as census, taxation, construction, environment etc. and provides public access to data ${ }^{107}$.

\subsubsection{First-registration}

First-registration is a process that enables the first entry of an object in a land register/cadastre. In a developing country context, the challenge lies in engineering a feasible process that produces trustworthy results. The first of the three classic methods of first-registration (Larsson 1991, p. 80-82 ${ }^{108} / 109$ ) is voluntary sporadic registration ${ }^{110}$, which is done at the landholder's expense and therefore needs only minimal public investment. This method prevails in the developing world, but it has never achieved good area coverage. Second is compulsory sporadic registration, which obliges registration upon transaction ${ }^{111}$. Bogaerts and Zevenbergen (2001 p. 334-335) note that while sporadic registration provides problematic legal security for a third party, and struggles to cover entire areas, it is at least a client-driven process that concerns only the parties involved and does not stir up dormant problems. In Cambodia, sporadic registration managed to handle only a fraction of claims ${ }^{12}$ (Törhönen 2001, p. 410-411). The sporadic approach did not prove

\footnotetext{
${ }^{96}$ The recordings expanded from 120000 in land book in 1901 to nearly 1,6 million in 1980 (Heikkilä 1983, p. 380).

${ }^{97}$ Many, larger, municipalities still have separate cadastres.

${ }^{98}$ The Finnish system falls in between deed and title register systems. Until 1997, the register did not enjoy public liability and the evidence of title remained with a recorded transaction deed (by the court). Still, the land title and mortgage certificates were issued based on the title register content (that had no legitimacy) (Hyvönen, 1998 p. 142).

${ }^{99}$ Maintained by the National Land Survey under the Ministry for Agriculture and Forestry

${ }^{100}$ The key laws, on land tenure and formation (Hyvönen 2001, p. 1-34), have been enforced since 1997.

${ }^{101}$ A notable inconvenience caused by the authority may lead to a monetary compensation (Hyvönen 1998, p. 165-167).

${ }^{102}$ The constitution protects individual property. It may only be altered in the public interest with full compensation.

${ }^{103}$ Mapping started properly in the 1920's and progressed during the past decades until by 1980 it covered practically all land.

${ }^{104}$ A recent stipulation will change this from 1.6.2005 onwards (Kokkonen 2002).

${ }^{105}$ Before the reform a landholder had to confirm title three times with different authorities in the subdivision process.

${ }^{106}$ The Real Estate Information System and its successor JAKO carried the real property system to the Internet.

${ }^{107}$ Recently JAKO introduced topographic data to the system and soon planning data will also be inserted.

${ }^{108}$ Larsson refers to the "establishment of a title register", but I interpret this to cover all first-registrations. While sporadic registration tends to serve deeds registers and systematic title registers, variations are numerous.

${ }^{109}$ Sporadic and systematic registration in Simpson 1976, p. 189-207, FIG 1995, Dale \& McLaughlin 1998, p. 29-30 ...

${ }^{110}$ Often connected to the register of deeds, which was explored in the previous Chapter.

${ }^{111}$ The problems of such a system are explored in Chapters 2.2. and 2.3.

${ }^{112}$ In 1992, 4,5 million claims were made and only 10 percent of urban residential and business parcels, were registered.
} 
feasible on a large scale. Since that time, first-registration has taken place based only on an informal contract between the land register and the claimant, who has financed the entire action. The result is that a great majority still do not have titles.

The third method, of systematic registration, whereby a whole area is adjudicated and surveyed at one time, is preferable. The cost per unit is low, rights are adjudicated once and for all, public information is effective and conflicts automatically come to light (Larsson 1991, p. 81-82). After concluding in Cambodia that sporadic registration was not going to reach the poor ${ }^{113}$ (the majority), and was not a good basis for land management, new alternatives were explored (Törhönen 2001, p. 414-415). While the land administration system was struggling to revive it was important that an equitable land registration system was in place, with maximum transparency, publicity and communal participation. Field visits were unavoidable, since people had practically no documentary evidence about their holdings. Systematic registration seemed to provide the only possible solution.

The classic steps of systematic registration are: adjudication ${ }^{114}$ of rights, demarcation of boundaries, survey of the extent and documentation for registration (HABITAT 1990 p. 15, Dale \& McLaughlin 1988, p. 28, Simpson 1976). I conducted a pilot project for systematic registration in Zanzibar (Törhönen 1998a, p. 6975). A simple procedure was developed, which apart from slight technical and approach ${ }^{115}$ problems functioned well, but the logistics involved in claim recording, adjudication, demarcation and survey proved suffocating. It was difficult even to call the claimants effectively for the fieldwork, not to mention any other interested parties. It is noted that the public information work was not limited to the campaign. Field teams were engaged in continuous information dialogue with landholders. All staff had to be well trained in order to avoid misinformation ${ }^{116}$. Later in Zimbabwe, we were looking at technical solutions for rural titling (Törhönen and Goodwin 1998, p. 103 -107). We suggested that general (mutually agreed) boundaries could be geometrically simplified at the time of survey, that rural landholders were able, with assistance, to identify parcel boundaries from an aerial photograph and finally that the adjudication, demarcation and surveys should be done during only one visit to a parcel if the exercise was to be economic. Finally, Cambodia proved to be a difficult challenge (Törhönen 2001, p. 415 - 420). Since the surveying and law professions had been destroyed, non-professionals would operate the system in future. All lands were to be covered, every parcel visited and the testimonies of witnesses used as primary evidence for adjudication. The technology level had to be adjusted to suit local conditions. In an effort to avoid logistical problems the registration was designed to go to the people only once. A public appeal mechanism was set up to ensure the equality of right holders. The result is a six-step ${ }^{117}$ low manpower ${ }^{118}$ systematic registration that can be completed in one session. It is based on community participation, the testimonies of witnesses and on photointerpretation. Any appeals are displayed at the centre of each community, and a commission drawn from both the people and government settles appeals before a court. The logistics are simple; the team approaches people on their parcels with the help of the village leader ${ }^{119}$. The system is fast, easy and cheap (Törhönen 2001, p. 421-424). Probably the most important reason for success has been the people's desire for title. The difference between this and Zimbabwe's communal lands, for example, is that in Cambodia the registration exercise is not to introduce a private tenure system but rather to reinstate one. Pre-crisis holdings were not given back, but people were already familiar with the concept of private tenure and felt that titling was a step towards the days of stability and prosperity. This makes all the difference. In Uzbekistan, in contrast, I witnessed such a low desire for change that I believe it would not enable the same kind of participatory concept (Törhönen 2002, p. 7).

\footnotetext{
${ }^{113}$ WB concluded that sporadic titling is cost effective but favours the powerful (Deininger and Binswanger 1998).

${ }_{114}$ Adjudication (Dale \& McLaughlin 1998, p. 47-49, Larsson 1991, p. 101-111, Habitat 1990, p. 15-16, Dale \& McLaughlin 1988, p.231-233, Simpson 1976, p. 194-206).

${ }^{115}$ Fixed boundaries were a mistake as the trees were valuable and boundaries followed them flexibly. The thick rural vegetation made the boundary lines invisible and photointerpretation and GPS surveys unfeasible. Bogaerts and Zevenbergen (2001 p. 331-333) recommend the adoption of general boundaries and index mapping instead of fixed boundaries, which require more accurate surveying. Yet, the choice has often matured over centuries.

${ }^{116}$ Dale \& Binns (1995, p. 74-81) had a similar notion in their very practical book about cadastral surveys.

${ }^{117}$ Public Information, Adjudication, Demarcation, Surveying, Documentation and Appeal.

${ }^{118}$ Designed for one officer and landholder to execute, but teams have had both adjudication and a demarcation officers.

${ }^{119}$ Natural leaders' importance also stressed by Dale \& Binns (1995, p. 74-81).
} 
The Finnish experience is not directly comparable to first-registration in developing countries, but it is interesting to note that it took two centuries to go through all properties in the great consolidation ${ }^{120}$ (Saarenheimo 1983). Although it was a larger task than registration, it highlights the magnitude of such work on a national scale. Note that in Finland a single surveyor lived in a village and surveyed parcels within the village. This could possibly be a way forward for first-registration in very low resource conditions. It could be done on a "private surveyor" basis whereby each surveyor would collect income directly from the villagers, which is similar to what happened in Finland. It would need the state to set up, maintain and monitor a central system, and it would need considerable input by the landholders, perhaps only attainable in places with a high desire for title. This could be explored further.

\subsection{Development Project}

Land administration has become a key target of development cooperation. The justification often stems from Western experiences. For example, Bogaerts and Zevenbergen (2001 p. 334) point out that about $60 \%$ of the wealth of Western nations lies in real property; a form of wealth secured by land administration. De Soto (2000) showed the significance of liquid property to success in the West, and the potential that developing countries have in this regard. Agenda $21^{121}$ linked proper land management ${ }^{122}$ to sustainable development and reached a consensus on the importance of land management to developing countries. The Bathurst declaration ${ }^{123}$ took this a step further, saying that sustainable development is not attainable without sound land administration (UN FIG 1999). The enormity and severity of developing country land issues is well known (UN FIG 1999, p. 4) and the expected benefits of land administration and land management are widely publicised (Dale \& McLaughlin 1998, p. 2, Dale \& Binns 1995, FIG 1995, Larsson 1991, p. 57-69, HABITAT 1990, p. 5-6, Dale \& McLaughlin 1988 and Williamson 1986). Back in 1972 Lawrance wrote that inadequate land records have a direct and adverse effect on development; registration provides stimulation to land markets, security for credit and data for planning. Adding only a positive impact on the environment, the expected benefits seem not to have changed in three decades. Today, land administration development projects involve many bilateral ${ }^{124}$ and multilateral donors. It is safe to say that all projects aim at sustainable development, which ties in well with donor agendas as seen in Cambodia ${ }^{125}$ (Törhönen 2001, p. 424-426).

But there is no general consensus. Dale \& McLaughlin (1998, p. 3-4) summarise the criticism mounting against the importance of land and property. The potential for customary tenures systems to provide secure and progressive tenure is recognised. This is news to no one, but only now has it been taken seriously ${ }^{126}$. Other critical notes concern the non-obvious linkage between secure tenure and a functioning credit system, the fact that an aim of optimised land use may actually result in the accumulation of land for speculation, and the fact that the costs of maintaining property infrastructure may be so high that developing countries might have more urgent priorities. Place \& Hazell (1993) saw no need for ambitious registration projects in SubSaharan Africa. They found no significant correlation between the type of land rights and farmers' interest in investing ${ }^{127}$. Birgegård (1993), in an African context, does not believe in tenure reform and land titling. He has researched the land titling exercise in Kenya a few decades back, and his conclusions are not flattering. Titling decreased security of tenure, promoted inequality, weakened the position of women, especially

\footnotetext{
${ }^{120}$ Explored in Chapter 2.2.3.

${ }^{121}$ The declaration for implementing sustainable development; the Rio Conference on Environment and Development in 1992. Sustainable development based on three equal pillars: environmental protection, improving the social condition of the poor and poverty reduction.

${ }_{122}$ Meaning land management in the broadest sense including the components of land administration.

${ }^{123}$ UN - FIG Bathurst declaration on land administration for sustainable development. (Williamson and Grant 2002)

${ }^{124}$ For example AusAID (2000) recently concluded that these projects potentially reduce rural poverty and increase security of tenure by boosting the positive economic growth, social stability and sustainable management of resources.

${ }^{125}$ The intended national registration program demonstrated its potential for protecting the environment and promoting social equity, democracy and human rights, which are the strategic objectives of Finland's development co-operation policy.

${ }^{126}$ Explored in Chapter 2.2.

${ }^{127}$ For example, farming techniques and access to credit were more relevant factors than the types of land rights.
} 
weakened secondary rights ${ }^{128}$, increased landlessness and had no effect on land or credit markets. Birgegård suggested that in Africa customary tenures are more flexible and function better than statutory ones.

These criticisms have had an affect. For example, the International Federation of Surveyor's (FIG 2001) now promotes fair access to land, an indiscriminate provision of security of tenure and pays attention to women and indigenous groups. Birgegård's conclusions were, however, criticised by Borges (1993), who noted that Kenya's land titling was too advanced for the 1960's and argued that today's Africa is different. The same may be said about land titling. Programs of the 1960's and today have little in common. The problem with Birgegård's conclusions, as in numerous pro-titling ones, is that land titling has been vaunted as a potential answer to a variety of ills. A typical list of benefits to be expected in a land titling program portrays every developing country as turning automatically into a developed one. As Dale \& McLaughlin (1998, p. 4) put it, land administration is necessary but not sufficient for solving the problems underlying development, and the same conclusion was reached by the World Bank (Deininger and Binswanger 1998). Should the outcome of titling then be researched in isolation from overall development? The land titling outcome in Thailand, enroute to becoming the economic Tiger of Asia, was judged to be good. The result in Kenya was judged poor when Kenya's progress was not as evident. This might be jumping to conclusions and over-simplifying the complex issues involved, but the point is worth making. Deininger \& Binswanger (1998) stress that the goals of a land titling program have to be clear, and neither numerous nor divergent (also AusAID 2000). The challenge lies in the creation of effective and affordable systems that serve both government and the people (AusAID 2000). The timeframe required is long, probably closer to tens of years than years ${ }^{129}$. Turning to actual practice, the World Bank has started to fine-tune the preconditions that had to be met before a land titling program (Deininger and Binswanger 1998). Justification and understanding ${ }^{130}$ appear to be at an advanced level, so why are there so few accounts of implementation? I hope it does not only mean that the terminology has changed. Hopefully new initiatives really are target and people-oriented. Based on my experience and this research, I am afraid that implementation generally lags far behind universally agreed approaches and ideas.

\section{Key Issues Behind Sustainable Land Tenure and Land Registration in Developing Countries}

In this article, I have investigated the framework behind sustainable land tenure and land registration. My aim is to contribute to the design of land administration development in developing countries. I will now structure the research findings (giving the source chapters in brackets), select key issues, and evaluate their relative impact a) on the feasibility of land administration and b) on sustainable development (Table 1). My intention has not been to create a checklist ${ }^{131}$ for land administrators, but only to highlight significant variables. Final conclusions are summed up in the next chapter. Note that conclusions are drawn only for a developing country context. Their applicability to industrialised countries has not been considered, and it also has to be understood that they will not be valid for every developing country. Still, the key issues display similar features and consequences.

Land policy is a guideline, a tool and the recommended starting point for land administration. Lack of clear policy results in scattered land administration without a common goal (Cambodia, Zimbabwe). On the other hand, the presence of land policy without the means of implementation (Zanzibar) is no better. Land management is a creative activity that aims at sustainable land use, and land administration is an implementer that follows and enhances the law. Land management activities may be wasted without functional land administration (Cambodia, Zimbabwe), in which case planning is disconnected from reality, and reforms or development initiatives are likely to have little impact (Cambodia, Zimbabwe). Land administration requires a clear hierarchy and procedure otherwise informal and formal authorities will

\footnotetext{
${ }^{128}$ A similar Zanzibar experience is described in Chapter 2.2.1.

${ }^{129}$ As concluded in the previous Chapter concerning first-registrations.

130 See FIG 2001, FIG 2001a, UN FIG 1999 and FIG 1991 for surveyors' expanding understanding on the land issues.

${ }^{131}$ The FIG guidelines (2001a) discuss criteria for evaluating the success of land intervention in terms of "women's access to land and the benefits of land". More general criteria and checklists are found in Larsson 1991, Dale \& McLaughlin 1988 and Williamson 1986. I tested the latter three in Törhönen 1998a and 1998b.
} 
compete, resulting in administrative anarchy (Zimbabwe, Zanzibar). Even a nominal rule that vests lands in the state will make the position of landholders worse by providing de facto unlimited powers to the authorities (Zimbabwe, Cambodia, Zanzibar). (Chapter 2.1)

Various land tenure types co-exist in developing countries. The recognition only of statutory tenures tends to marginalise a large sector of society. Not to recognise secondary, often temporary, rights endangers foodsecurity and social stability. Customary tenure systems have tended to provide wide access to land, ensuring the survival of generations through, for example, (semi)-subsistence farming, hunting and fishing (Zanzibar, Finland, Zimbabwe) while enabling adequate security of tenure for development. Given the right circumstances, customary land tenure structures may be mutually beneficial both to primary and secondary right-holders (Zanzibar, Finland), but seem to lose the ability if the economic situation changes drastically. Following such a change, secondary right-holders become vulnerable, which may result in insecurity of tenure that can have severe impacts on social stability (Zanzibar, Finland). Customary tenure is often weakened by modern pressures and by co-existence with statutory tenures. Poorly executed land reforms exacerbate the situation. The result is a multi-layer tenure system without clear rules. But can a modern land administration recognise customary tenure or multi-layer tenure feasibly? Hardly, especially because secondary rights are too dynamic to classify or record, and possibly these rights may be more secure if left untouched. Still, customary tenure systems can be, and have been, recognised in statute. Compromises such as communal title can be criticised for their ability to adapt to changing conditions and on their potential to contribute anything more than customary tenure. On the other hand, a Nordic common right is an example of secondary rights to land that are both broad and publicly accessible. This could be researched further in this context. It is important to recognise the point that it is often not the type but the level of security of tenure that affects a vast number of issues. Land tenure, whether forced or unforced, is an evolution. For sustainable results it should either be supported or else left undisturbed. One critical juncture is when a group, exercising communal land tenure at an early stage of evolution, needs to deal with another group many steps forward. Customary landholders facing commercial interests are vulnerable, and may need support. (Chapters 2.2, 2.2.1 and 2.2.2).

The preservation, through use and transfer restrictions, of a tenure type for a noble reason such as protection of an indigenous culture or of a communal tenure pattern (Zanzibar, Finland), is doomed to failure. Permanent restrictions potentially boost the informal market and may even speed up the fall of the tenure type and culture. Groups, cultures and livelihoods have to be free to develop, and no group should be consigned to a land tenure terrarium for others to admire (Chapters 2.2.3.1, 2.2.3.3). Customary tenure groups facing commercialisation may need protection, and perhaps also transfer restrictions, but these should not be permanent. Successful land reforms seem to be possible so long as they are fair and systematic, create vibrant tenure systems and allow mutation. Vibrant tenure seems to require a gradual freeing up of land use, inheritance and transfer (Chapters 2.2.3, 2.2.3.1 and 2.2.3.2). Weak authorities in land redistribution reforms are vulnerable to externalities, as happened in the surplus-acquisition valuations in Finland. A low-paid surveyor was tempted to accept benefits for a valuation that favoured the landowner. The land reforms researched, with certain exceptions, had unexpected consequences, both positive and negative. This supports the theory that created tenure systems have to be flexible to adapt to changing conditions and should not be restricted to their original aims. The best setting for a land distribution reform seems to have been provided by a post-conflict situation where a mood of solidarity can overcome personal interests. (Chapters 2.2.3, 2.2.3.1, 2.2.3.2 and 2.2.3.3)

Land registration systems are unique reflecting their host societies. A functioning deeds system may be the best that a developing country can afford, but it potentially serves neither the best interests of the state nor the poor majority (Cambodia). An improved deeds system could be a desirable option, so long as it is based on affordable fees, is fair and is free of informal payments. However, it would most likely serve only the interests of the wealthy (Zanzibar, Cambodia). It is not ideal but may still be better than failed title registration that may cause previously existing systems to collapse. A title system should only be introduced if there is a certainty of implementation, something that requires a strong land administration structure and a high level of motivation of the people. The weak legal position of unregistered rights is problematic. If only registered rights are legal, then the reality is that most rights will be illegal due to the existence of unregistered primary rights and unrecognised secondary rights. The situation is made worse if no feasible 
way of registration is available (Cambodia, Zanzibar). An absolute guarantee of title seldom fits the circumstances of developing countries. It is likely to boost informal tenure and the informal land market contrary to its aim i.e. it will lessen security of tenure. Registration systems that require professional services for transactions are likely to remain out of reach of the poor. Systems should technically be so sound that no repeated adjudication or surveys are required for transactions. If a land administration system fails, an informal system will replace it. The fact is that all habitable land property is administered (and subject to interests) formally or informally. (Chapter 2.3)

The connection between land registration and taxation may make it unattractive to people (Cambodia) even if it may benefit them as much as government. A modern cadastre can be legal or fiscal and may serve both public and private interests. The challenge is to establish practical, equitable, public systems. Land registration or cadastre development is a slow process; it took centuries in Europe. Cadastres evolve and their purpose and the tasks they perform vary over time. The first property taxation records in Finland date back to the $13^{\text {th }}$ century, but a comprehensive cadastre was only achieved last century. In principle, a separate title register and cadastre are a duplication of resources. However, Finland's example shows a) how technical unification provides a way for improvement, if a formal unification is unattainable and b) that public liability can be at a high level without a formal state guarantee on the records. A modern land administration system is interlinked to different authorities and provides wide public access to information, serving the private and public sectors equally. (Chapter 2.3)

Sporadic first-registration may be the only affordable way for a country, but it cannot cover the majority of property rights. Informal payments make for a sporadic system that serves only the wealthy. Systematic registration may suffer from logistical problems (Zanzibar) if not carefully designed for local conditions. To be feasible, all legal and technical work must be executed during one visit per parcel (Cambodia, Zimbabwe). Such a thing is possible at least in a rural setting with structured local government. Landholders may be used as survey assistants, witnesses and more. A public procedure that embodies a fair appeal period thereby ensures social control and should result in an equal treatment of claimants. Desire for title, a key to success, is likely to be high if the titling process reinstates something that has existed previously (Cambodia), but introduction from scratch may face strong resistance (Uzbekistan) and close the door to participatory approaches. The time span for first-registration on a national scale is likely to be long. It may be possible to create a largely self-financing first-registration system based on the efforts of private surveyors and the landholders' own input. Such a thing requires investment in an umbrella system by the state and also a high desire for title among the public. Finnish land reforms were done in this manner during eras of very low resources. (Chapter 2.3.1)

There is wide consensus on the benefits of a functioning land administration system for a developing country. Critics can be found, and the international forum is generally quick to adopt the language of the critics, but at least at present, customary tenure gets the recognition that it deserves. It has to be understood that land administration development cannot be isolated from overall development. Tight preconditions are appropriate before investing in a land administration system. It is hoped that new land administration projects will be better than old ones and not only that the language has changed. (Chapter 2.4)

The following framework summarises my interpretation of the key issues behind sustainable land tenure and land registration (Table 1). The ratings I have assigned are based on this research. Throughout the research I have used more qualitative than quantitative methods, which leaves some level of subjectivity in the evaluations. It is noted that a five-level rating for the relative impact evaluation may be too exact, and perhaps a scale of negative-neutral-positive would have been more appropriate. But there appeared to be degrees of negativity and positivity, which is why I used a five-level rating. Finally, I need to stress that in the end key issues and the main ratings became very clear. 
Table 1. Framework for sustainable land tenure and land registration; impacts on feasibility of land administration and sustainable development

Key issues

Lack of land policy

Land policy creation, a starting point for investment on land administration

Ambitious land policy, appropriate resources

Ambitious land policy coupled with low resources

Land management without proper land administration

Ambiguous land administration organisation and duties

Well organised land administration

Land vested in the state, low resources

Informal land administration prevails

Informal land administration prevails but not recognised

Statutory tenure recognised, customary tenure ignored

Primary right registration in multi-layer tenure situation

No register in multi-layer tenure condition

Only registered right recognised by law

Only registered right recognised by law + informal payments

Customary tenure balanced by mutual-benefit

Customary mutual-benefit balance in changing conditions

Customary tenure land faces external commercial interests

Customary holders supported when facing commercial interests on their land

Insecure tenure for secondary right holders

Secure tenure for secondary right holders

Individually registered tenure for all secondary right holders

Poorly implemented land reform in multi-layer tenure situation

General recognition of a customary tenure form

Unforced land tenure evolution

Forced land tenure evolution

Arrested land tenure evolution

Land tenure with permanent use restrictions

Land tenure with speculative inheritance

Land tenure with permanent restrictions on transfer

Short-term transfer restrictions in forced land tenure evolution

Customary tenure protected by statutory restrictions

Redistributive land reform in a unified country

Redistributive land reform in a divided country

Redistributive land reform by a weak authority

Deeds registration

Improved deeds registration

Poorly introduced register of titles

Comprehensive, maintained, register of titles

Register of titles in a multi-layer tenure area

Absolute guarantee of titles

Registration requires professional services for transactions

Connection between registration and taxation

Connection between registration and taxation as a first priority

Short term investment in cadastre or land register

Long term investment in cadastre or land register

Separate legal and fiscal registers

Technically unified legal and fiscal registers

Unified legal and fiscal registers

Liability by absolute guarantee of title coupled with low quality register

Public liability due to high quality of records

Land records for security of tenure

Land records for public sector support

Land records shared for private and public use

Sporadic registration

Insensitive systematic registration

Simultaneous, participatory systematic registration, high desire for title

Simultaneous, participatory systematic registration, low desire for title

Participatory systematic registration, structured local government

Participatory systematic registration, scattered local government

Public, fair, appeal process

Short term external input for systematic registration

Long term external input for systematic registration

Private surveyor titling with input from landholders
Impact on feasibility of a land administration

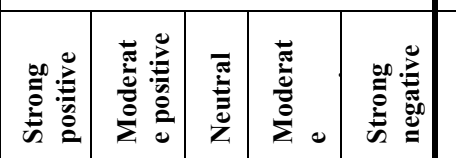

\begin{tabular}{|l|l}
\hline $\mathrm{X}$ & \\
\hline & $\mathrm{X}$
\end{tabular}

\begin{tabular}{l|l}
$\mathrm{X}$ & - \\
\hline
\end{tabular}

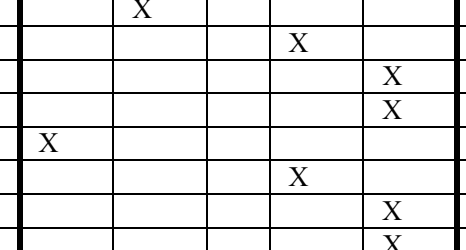

\begin{tabular}{|l|l|l|l|l|}
\hline & & & & $\mathrm{X}$ \\
\hline & & & & $\mathrm{X}$ \\
\hline $\mathrm{X}$ & & & $\mathrm{X}$ & \\
& & & & \\
\hline & & & & $\mathrm{X}$ \\
\hline
\end{tabular}
列

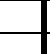

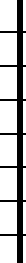

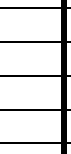

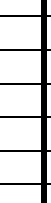

\begin{tabular}{|c|c|c|c|c|}
\hline & & & $X$ & \\
\hline & & $X$ & & \\
\hline & & $\mathrm{X}$ & & \\
\hline & & & $X$ & \\
\hline & & & & $X$ \\
\hline & & $X$ & & \\
\hline & & & $X$ & \\
\hline & & $X$ & & \\
\hline & & & $X$ & \\
\hline & & & & $X$ \\
\hline & $X$ & & & \\
\hline & $X$ & & & \\
\hline & & & & $X$ \\
\hline$X$ & & & & \\
\hline & & & $X$ & \\
\hline & & $X$ & & \\
\hline & & & $X$ & \\
\hline & & & $X$ & \\
\hline & & . & & $\mathrm{X}$ \\
\hline & & $X$ & & \\
\hline$X$ & & & & \\
\hline & & & $X$ & \\
\hline & $X$ & & & \\
\hline$X$ & & & & \\
\hline & & & $\mathrm{X}$ & \\
\hline & $X$ & & & \\
\hline & & $X$ & & \\
\hline & & $X$ & & \\
\hline & & $\mathrm{X}$ & & \\
\hline & $X$ & & & \\
\hline & & & & $X$ \\
\hline$X$ & & & & \\
\hline & & & $X$ & \\
\hline & $X$ & & & \\
\hline & & & $\mathrm{X}$ & \\
\hline & $X$ & & & \\
\hline & & & $X$ & \\
\hline & $X$ & & & \\
\hline & $X$ & & & \\
\hline
\end{tabular}

Impact on sustainable development

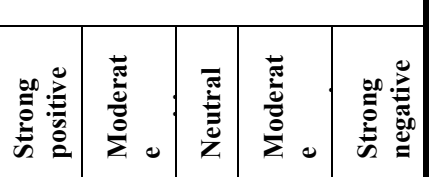


Real property supportive preconditions for land administration investment

Loose supportive preconditions for land administration investment

\begin{tabular}{|l|l|l|l|l|l|l|l|l|l|}
\hline & & $\mathrm{X}$ & & & & $\mathrm{X}$ & & & \\
\hline & & $\mathrm{X}$ & & & & & & $\mathrm{X}$ & \\
\hline
\end{tabular}

\section{Conclusions}

The above framework for sustainable land tenure and registration reveals just how complex and multidimensional land administration, land tenure and land registration development is in developing countries. The establishment and maintenance of viable, national level land administration ideally requires good governance (clear policies, proper organisation, no corruption), adequate resources, a culturally sensitive approach (participatory [systematic] registration, high desire, appropriate fee levels, not necessarily registration), equity (appeal period, communal control), quality (liability, unified register) and commitment (long term investment, tight preconditions). If all or most of these apply, with resources as a precondition, land administration development on a national scale has the potential to meet its objectives. Land administration becomes unworkable where there is ambiguity in governance (lack of policies, scattered organisations, abstract land management, informal administration), inadequate resources (failed reforms or titling), low legality (misuse of state land principle, informal fees), insensitive approaches (exclusive statutory tenure, low security of unregistered and secondary rights, enforced land tenure evolution, external professional services for transfers, systematic registration coupled with low desire, unrealistic absolute guarantee of titles), excessive control (use and transfer restrictions) and lack of commitment (short-term investment, loose preconditions). If, disturbingly, most of these apply, then the best solution might be to aim for less ambitious goals and merely to prepare a land policy, create a simple unified land administration organisation, recognise and support customary tenure structures, aim to establish a fair and gradually improved register of deeds with simple sporadic methods, and only to consider self-financing, systematic registration when legal enforcement and resources improve.

Workable land administration is in itself one of the factors behind sustainable development. But many of its key issues also have tangible significance. Very positive factors are associated with land tenure, including balance (mutually benefiting customary tenure), security (primary and secondary rights on land, covering and updated register of titles) and flexibility (unforced land tenure evolution). In a nutshell, a secure, flexible, all-inclusive tenure form, whether customary or statutory, provides the best basis for development. Less tangible positive impacts can be expected from good governance (policies, organisations, taxation), an appropriate approach (technical unification and quality, data sharing, functioning deed system, recognised customary tenures), land distribution (successful reforms, supported customary tenure transitions) and commitment (long term investing, tight preconditions). If ambiguity (abstract land management, competing formal and informal administration), low legality (misuse, informal fees), insecurity (no recognition of unregistered or secondary right, absolute guarantee of primary rights), insensitive approaches (exclusive statutory tenure, halted land tenure evolution, permanent restrictions, contracted sporadic registration), low resources (failed reforms or titling) and a lack of commitment (loose preconditions) prevail, then land administration will significantly disrupt sustainable development. In other words, an ambiguous, ineffective land administration that fails to serve a large part of the population and promotes insecurity of tenure is a harmful institution.

\section{References}

Åberg V. 1983. Maanhankintalain toimeenpano (Implementation of the Land Acquisition Law) in the Maanmittaus Suomessa 1633 - 1983 (Surveying in Finland 1633 - 1983). Pages 286-307. Maanmittaushallitus. Helsinki.

AusAID 2000. Improving Access to Land and Enhancing the Security of Land Rights: A Review of Land Titling and Land Administration Projects. Quality Assurance Series no. 20/2000. Australian Agency for International Development.

Aspelund A. R. R. 1983. Vuokra-alueiden itsenäistäminen ja asutustoiminta ennen toista maailmansotaa (The Privatisation of Leaseholds and Housing Activities Before the Second World War) in the Maanmittaus Suomessa 1633 - 1983 (Surveying in Finland 1633 - 1983). Pages 218-243. Maanmittaushallitus. Helsinki.

Barnes, G. 1990. A Comparative Evaluation Framework for Cadastre-Based Land Information Systems (CLIS) in Developing Countries. Land Tenure Center Research Paper 102. University of Wisconsin-Madison.

Birgegård, Lars-Erik 1993. Natural Resource Tenure - A Review of Issues and Experiences with Emphasis on Sub-Saharan Africa. Swedish University of Agricultural Sciences, International Rural Development Centre. Rural Development Studies no. 31. Uppsala Bogaerts T. and Zevenbergen J. 2001. Cadastral Systems; alternatives. Computers, Environment and Urban Systems; Theme Issue Cadastral Systems, vol. 25 no. $4-5$ (2001) p. 325-337. PII: S0198-9715(00)00051-X. Elsevier Science Ltd. 
Borges, K. E. 1993. Natural Resource Tenure - some preliminary comments. Unpublished commentary. Royal Institute of Technology. Stockholm.

Dale P. F. \& Binns B. O. 1995. Cadastral Surveys and Records of Rights in Land. Original study 1953 by Sir Bernard O. Binns, 1995 revised Peter F. Dale. FAO Land Tenure Studies nr 1. Rome.

Dale, Peter and McLaughlin, John 1999. Land Administration. Oxford University Press. London.

Dale, Peter and McLaughlin, John 1988. Land Information Management; an Introduction with Special Reference to Cadastral Problems in Third World Countries. Oxford University Press. London.

Deininger, K. and Binswanger H. 1998. The Evolution of the World Bank's Land Policy: Principles, Experiences, and Future Challeges. Internal Discussion Paper. The World Bank. Washington DC.

De Soto, Hernando 2000. The Mystery of Capital; Why Capitalism Triumphs in the West and Fails Everywhere Else. Bantam Press. London.

FIG 1991. Statement on Environmental Issues. International Federation of Surveyors FIG $58^{\text {th }}$ Permanent Committee Meeting. Beijing.

FIG 1995. The International Federation of Surveyors Statement on the Cadastre. International Federation of Surveyors FIG publication no. 11. ISBN 0-644-4533-1.

FIG 2001. FIG Agenda 21. International Federation of Surveyors FIG publication no. 23. ISBN 87-90907-07-8.

FIG 2001a. Women's Access to Land - FIG Guidelines. International Federation of Surveyors FIG publication no. 24, Katalin Komjathy and Susan E. Nichols,. ISBN 87-90907-08-6.

Australian Government Publishing Service. Canberra.

Fourie C. and Hillermann R. 1995. Examining the Relationship Between the National South African Cadastre, Indigenous/Informal Land Tenure Systems and Low Level Land Administration. University of Natal, Durban, South Africa. Paper at the FIG/CASLE Symposium on "Sustainable Development: Counting the Cost - Maximising the Value". Harare.

GTZ, 1998. Land Tenure in Development Cooperation; Guiding Principles. Deutsche Gesellschaft fûr Technische Zuzammenarbeit (GTZ) Gmbh. Schriftenreihe der GTZ, No. 264. Wiesbaden.

Habitat 1990. Guidelines for the Improvement of Land-Registration and Land-Information Systems in Developing Countries (with special reference to English-speaking countries in Eastern, Central and Southern Africa). United Nations Centre for Human Settlements, Nairobi, Kenya.

Heikkilä H. 1983. Kiinteistöjen rekisteröinti (Real Property Registration) in the Maanmittaus Suomessa 1633 - 1983 (Surveying in Finland 1633 - 1983). Pages 359-389. Maanmittaushallitus. Helsinki.

Henssen J. L. G. 1994. Multi-purpose Cadastre, a component of land management with a low cost aspect. FIG XX. International Congress, Melbourne, Australia, Congress Proceedings TS 701.2/1-10. Melbourne.

Hyvärinen H. J. 1995. Suomen kolttasaamelaisten oikeudellisesta asemasta (The legal status of the Skolt-Sami ). p. 22-24 in Saarinen T. and Suhonen S. 1995. Koltat, karjalaiset ja setukaiset; pienet kansat maailmojen rajoilla (Skolt-Sami, Karelians and Setu; small nations on the borders of worlds). Snellman instituutin A-sarja 19/1995. ISBN 951-842-167-6. ISSN 0781-1861. Snellman-instituutti. Kuopio.

Hyvönen V. O. 2001. Kiinteistönmuodostamisoikeus II; Kiinteistötoimitukset (Real property formation legislation I; Real property formations). ISBN 951-98394-1-0. Ky Veikko O. Hyvönen \& Co. Espoo.

Hyvönen V. O. 1998. Kiinteistönmuodostamisoikeus I; Yleiset opit (Real property formation legislation I; General grounds). ISBN 951-95355-9-4. Ky Veikko O. Hyvönen \& Co. Espoo.

Hyvönen V. O. 1982. Kiinteistöjärjestelmä ja kiinteistönmuodostamisoikeus (Land administration and real property formation legislation). ISBN 951-95355-2-7. Ky Veikko O. Hyvönen \& Co. Espoo.

Jutikkala E. 1983. Tilusjaot ja tilusmittaukset ennen isojakoa (Parcel Allocation and Measuring Before the Great Consolidation) in the Maanmittaus Suomessa 1633 - 1983 (Surveying in Finland 1633 - 1983). Pages 7-19. Maanmittaushallitus. Helsinki.

Kantee L. 1983. Siirtoväen asuttamisen merkityksestä (About the Significance of the Resettlement of Refugees) in the Maanmittaus Suomessa 1633 - 1983 (Surveying in Finland 1633 - 1983). Pages 319-320. Maanmittaushallitus. Helsinki.

Karanko R. 1983. Oikeudenkäynti maanmittausasioissa itsenäisyytemme aikana (Land Surveying Cases in Court During Our Independence) in the Maanmittaus Suomessa 1633 - 1983 (Surveying in Finland 1633 - 1983). Pages 390-399. Maanmittaushallitus. Helsinki.

Kokkonen A. 2002. Interview 29.5.2002 of Executive Director Arvo Kokkonen of the National Land Survey. Helsinki.

Laitinen E. 1996. Sankaritarina vai virheliike? Karjalaisen siirtoväen ja rintamamiesten asuttaminen toisen maailmansodan jälkeen (Epic or Mistake? The settlement of Karelian refugees and war veterans after the Second World War). p. 236-261 in Roiko-Jokela H. 1996. Siperiasta siirtoväkeen; murrosaikoja ja käännekohtia Suomen historiasta (From Siberia to settlement of internal refugees; crossroads and transitional eras in the history of Finland). ISBN 952-5092-04-6. Kopi-jyvä Oy. Jyväskylä.

Larsson G. 1991. Land Registration and Cadastral Systems; Tools for Land Information Management. Longman Group UK Limited. London.

Lawrance J. C. D. 1972. Some Observations on the Introduction of Registration of Title in Developing Countries. J.C.D Lawrance. On Cadastral Surveying and Urban Mapping, p. 9-20, October 1972. New York.

Libecap G. D. 1989. Contracting for Property Rights. ISBN 0-521-36620-8. Cambridge University Press. Cambridge USA.

Linkola M. and Sammallahti P. 1995. Koltanmaa, osa Saamenmaata (Koltanmaa, part of Lapland). p. 39-57 in Saarinen T. and Suhonen S. 1995. Koltat, karjalaiset ja setukaiset; pienet kansat maailmojen rajoilla (Skolt-Sami, Karelians and Setu; small nations on the borders of worlds). Snellman instituutin A-sarja 19/1995. ISBN 951-842-167-6. ISSN 0781-1861. Snellman-instituutti.

Luoma-aho E. J. 1991. Maa- ja metsätalous (Agriculture and Forestry) in the Luoma-ahon kyläkirja 1 (The Village of Luoma-aho 1). Pages 119-138. ISBN 952-90-2153-4. Gummerus Kirjapaino Oy. Jyväskylä.

Luoma-aho T., Luoma-aho T. T. and Ojajärvi E. 1991. Torpat (Peasat houses) in the Luoma-ahon kyläkirja 1 (The Village of Luoma-aho 1). Pages 64-68. ISBN 952-90-2153-4. Gummerus Kirjapaino Oy. Jyväskylä.

Luoma-aho T. T. and Ojajärvi E. 1991. Article Maanmittaustoimitukset (Land Surveys) in the Luoma-ahon kyläkirja 1 (The Village of Luoma-aho 1). Pages 45-63. ISBN 952-90-2153-4. Gummerus Kirjapaino Oy. Jyväskylä. 
Maurin A. 1992. Le Cadastre en France; Histoire et Rénovation. Editions du Centre National de la Recherche Scientifique. Paris Metropolitan Leo of Oulu 1995. Kolttien uskontoelämän historia ja nykytila (The history and present position of the religious life of the Skolts). p. 58-66 in Saarinen T. and Suhonen S. 1995. Koltat, karjalaiset ja setukaiset; pienet kansat maailmojen rajoilla (SkoltSami, Karelians and Setu; small nations on the borders of worlds). Snellman instituutin A-sarja 19/1995. ISBN 951-842-167-6. ISSN 0781-1861. Snellman-instituutti.

Mikkola J. J. 1941. Kolttakylän arkisto (Archive of a Skolt-Sami Village). Lapin sivistysseuran julkaisuja No. 8. WSOY Porvoo Helsinki.

NTFP Project, 1997. Land Security Options for Highland Communities; Ratanakiri Province, North East Cambodia. Natural Resources Factsheet (6) December 1997. Phnom Penh.

Ojanperä T. 1999. Maanjaot suomalaisessa historiankirjoituksessa (Land reforms in the history research of Finland). p. 11-29 in Rosenqvist O. 1999. Maanjaot ja maaseudun kehitys; lähtökohtia kiinteistöjaotusta muuttavien hankkeiden taloudellisten, yhteiskunnallisten, sosiaalisten ja kulttuuristen vaikutusten tutkimiseen. (Land reforms and rural development; Perspectives for the economical, societal, social and cultural impact assessment of land reforms). ISBN 951-39-0565-9. ISSN 1236-598X. Selosteita ja katsauksia nro 34. Jyväskylän yliopisto. Kokkola.

Place \& Hazell 1993. Productivity Effects of Indigenous Land Tenure Systems in Sub-Saharan Africa. Place, Frank and Hazell, Peter 1993. American Journal of Agricultural Economics 75, February 1993, p. 10-19.

Poutanen J. 1983. Maankäyttölainmukainen asutustoiminta (Housing Activities in Accordance with the Land Use Law) in the Maanmittaus Suomessa 1633 - 1983 (Surveying in Finland 1633 - 1983). Pages 321-335. Maanmittaushallitus. Helsinki.

Saarenheimo J. 1983. Isojaot ja isojaonjärjestelyt (Great Consolidations and New Consolidations) in the Maanmittaus Suomessa 1633 - 1983 (Surveying in Finland 1633 - 1983). Pages 20-62. Maanmittaushallitus. Helsinki.

Semenoja M. S. 1995. Suomen kolttasaamelaiset (The Skolt-Sami of Finland). p. 82-87 in Saarinen T. and Suhonen S. 1995. Koltat, karjalaiset ja setukaiset; pienet kansat maailmojen rajoilla (Skolt-Sami, Karelians and Setu; small nations on the borders of worlds). Snellman instituutin A-sarja 19/1995. ISBN 951-842-167-6. ISSN 0781-1861. Snellman-instituutti.

Sergejeva J. 1995. Kuolan saamelaiset, menneisyys ja nykyisyys (The sami of the Kola peninsula: past and present). ). p. 67-81 in Saarinen T. and Suhonen S. 1995. Koltat, karjalaiset ja setukaiset; pienet kansat maailmojen rajoilla (Skolt-Sami, Karelians and Setu; small nations on the borders of worlds). Snellman instituutin A-sarja 19/1995. ISBN 951-842-167-6. ISSN 0781-1861. Snellman-instituutti.

Simpson S. R. 1976. Land Law and Registration. Cambridge University Press. Cambridge.

Stein, R.T.J. and Stone, M..A. 1991. Torrens Title. Butterworths Pty Limited. Australia

Suomaa V. 1983. Vuoden 1936 asutuslain ja vuoden 1940 siirtoväen pika-asutuslain toimeenpano (Implementation of the 1936 Settlement Law and the 1940 Law on Immediate Settlement of Refugees) in the Maanmittaus Suomessa 1633 - 1983 (Surveying in Finland 1633 - 1983). Pages 265-285. Maanmittaushallitus. Helsinki.

Terho A. 1995. Lapinmaata jakamassa; Maanmittausneuvos Antti Pohjolan muistelmat (Land surveying Lappland; Memoires of HE Antti Pohjola). Kustannus Pohjoinen. ISBN 951-749-230-8. Oulu.

Törhönen M.-P. 2002. Land Tenure in Transition; Case Uzbekistan. Paper at the XXII FIG Congress; ACSM-ASPRS Conference \& Technology Exhibition 2002, pp. 8. Washington.

Törhönen M.-P. 2001. Developing Land Administration in Cambodia. Computers, Environment and Urban Systems; Theme Issue Cadastral Systems, vol. 25 no. 4-5 (2001) p. 407-428. PII: S0198-9715(00)00049-1. Elsevier Science Ltd.

Törhönen M.-P. 1998a. A Thousand and One Nights of Land Tenure; The past, present and future of land tenure in Zanzibar. Royal Institute of Chartered Surveyors, Our Common Estate -Series. ISBN: 0-85406-917-8, pp. 99. London

Törhönen M.-P. 1998b. Land Tenure Confused; Past, Present and Future of Land Management in Zanzibar. Helsinki University of Technology, Department of Surveying, Institute of Real Estate Studies. Publication series for real estate studies and land law, Serie A no. 18, pp. 135. ISBN: 951-22-4292-3. Espoo 1998.

Törhönen, M-P. and Goodwin D. P. 1998. Would a registry map hang comfortably in a round, mud hut? A Register of Title for Zimbabwe's Communal Areas: Philosophical and Technical Considerations. The Australian Surveyor Vol.43/No.2/1998, pp. 96-108. Törhönen, M-P. 1995. Varjoja paratiisissa? Sansibar tukee turismiin. (Clouds Looming over Paradise, Zanzibar Depends on Tourism). "Kehitys-Utveckling" magazine 3/95 pp. 18-19. Helsinki.

UN FIG (1999). Report of the Workshop on Land Tenure and Cadastral Infrastructures for Sustainable Development; the Bathurst Declaration and the Position Papers. United Nations and the International Federation of Surveyors. Workshop, 18-22 October 1999. Bathurst.

Vitikainen A. 1999. Maanjaot kiinteistöopin tutkimuksessa (Land reforms in the real estate studies). p. 30-45 in Rosenqvist O. 1999. Maanjaot ja maaseudun kehitys; lähtökohtia kiinteistöjaotusta muuttavien hankkeiden taloudellisten, yhteiskunnallisten, sosiaalisten ja kulttuuristen vaikutusten tutkimiseen. (Land reforms and rural development; Perspectives for the economical, societal, social and cultural impact assessment of land reforms). ISBN 951-39-0565-9. ISSN 1236-598X. Selosteita ja katsauksia nro 34. Jyväskylän yliopisto. Kokkola.

Vitikainen A. 2002. Interview 29.5.2002 of Professor Arvo Vitikainen of the Department of Surveying, Helsinki University of Technology. Espoo.

Williamson I. P. and Grant D. M. 2002. United Nations - FIG Bathurst Declaration on Land Administration for Sustainable Development; Development and Impact. Paper at the XXII FIG Congress; ACSM-ASPRS Conference \& Technology Exhibition 2002, pp. 12. Washington.

Williamson I. and Ting L. 2001. Land Administration and Cadastral Trends - a framework for re-engineering. Computers, Environment and Urban Systems; Theme Issue Cadastral Systems, vol. 25 no. 4-5 (2001) p. 339-366. PII: S0198-9715(00)00053-3. Elsevier Science Ltd.

Williamson, I. P. 1986. Cadastral and Land Information Systems in Developing Countries. The Australian Surveyor -Magazine. March 1986, Vol 33, No. 1, p. 27-43.

Wirilander J. 2001. Lausunto maanomistusoloista ja niiden kehityksestä saamelaisten kotiseutualueella (Statement on land tenure and its evolution in the Sami region). Government of Finland. 
Ylikangas H. 2000. Aikansa rikos - historiallisen kehityksen valaisijana (The Crime of the Era - Highlighting Historical Development). ISBN 951-0-25419-3. WS Bookwell Oy. Juva. 